\title{
Characterisation of particulate matter and identification of emission sources in Greater Caracas, Venezuela
}

\author{
Giobertti Morantes $^{1,2}$ (D) . Jean Carlos González ${ }^{2} \cdot$ Gladys Rincón $^{2,3,4}$
}

Received: 5 April 2021 / Accepted: 28 July 2021 / Published online: 13 September 2021

(C) The Author(s) 2021

\begin{abstract}
Between June and September 2018, particulate matter (PM) samples were taken in the Sartenejas Valley, southeast of Greater Caracas, Venezuela. The aim was to evaluate the morphology and the elemental chemical composition of particulate matter and establish possible emission sources during the rainy season. Functional groups were identified by FTIR spectroscopic analysis, and morphology and elemental composition were obtained by SEM-EDX analysis. The sampling period coincided with a Sahara dust storm. The SEM-EDX and FTIR analyses found evidence of mineral elements related to soil and crustal origins. The presence of C-rich or C-containing aerosols is related to biological sources or mineral carbon. SEM-EDX analysis of PM revealed the following particle groups: geogenic, metallic, C-rich, and secondary aerosols. Quantitative source appointments through principal component analysis (PCA) corroborated PM sources, including soil dust, sea salts, and reacted aerosols. According to the authors' knowledge, this study represents the first report to indicate that an episode of African dust could influence the particles collected in an intertropical continental sector in Venezuela, South America.
\end{abstract}

Keywords Particulate matter $\cdot$ SEM-EDX analysis $\cdot$ FTIR analysis $\cdot$ PCA $\cdot$ Emission sources $\cdot$ Venezuela

\section{Introduction}

Particulate matter (PM) refers to any substance, except pure water, that exists as a liquid or solid in the atmosphere under normal conditions and is microscopic or submicroscopic but larger than molecular dimensions (Seinfeld and Pandis 2016). PM can be classified according to its aerodynamic diameter $(D p)$ in $\mathrm{PM}_{2.5}(D p \leq 2.5 \mu \mathrm{m}), \mathrm{PM}_{10}(D p \leq 10 \mu \mathrm{m})$, and TSP (total suspended particles) $(D p \leq 70 \mu \mathrm{m})$. The $\mathrm{PM}_{2.5}$ is also called fine fraction and particles between

Giobertti Morantes

giobertti.morantesquintana@nottingham.ac.uk

1 Department of Architecture and Built Environment, University of Nottingham, Nottingham NG7 2RD, UK

2 Departamento de Procesos y Sistemas, Universidad Simón Bolívar, Laboratorio de Carbón y Residuales de Petróleo, Caracas, Venezuela

3 Facultad de Ingeniería Marítima y Ciencias del Mar, Escuela Superior Politécnica del Litoral, ESPOL, Campus Gustavo Galindo km 30.5 Vía Perimetral, P.O. Box 09, 01-5863 Guayaquil, Ecuador

4 Pacific International Center for Disaster Risk Reduction, ESPOL, Guayaquil, Ecuador
$2.5<D p \leq 10 \mu \mathrm{m}$ coarse fraction (WHO 2006). The most petite particle sizes (including $\mathrm{PM}_{2.5}$ ) have the most negative impacts on human health and climate change (Cohen et al. 2017; Yin et al. 2020; HEI 2019). In addition, PM may have a natural or anthropogenic origin; particles of natural origin come from soil erosion, resuspended soil dust, sea salt transport, forest fires, volcanic eruptions, and fractionated biological material emissions. Particles of anthropogenic origin result from human activities as vehicular traffic (mainly from vehicles with diesel engines), combustion and industrial processes, mining-metallurgical activity, and biomass burning (Aragón-Piña, 2011a, b).

Studies have been set to describe the Venezuelan air quality using PM as an indicator, including the research by Guajardo et al. (2010) about PTS-annual in Caracas between 1981 and 2006, in six stations belonging to the Ministry of the Environment of that country. Venezuela exceeded its standard in two stations (PTS-annual $<75 \mu \mathrm{g} \mathrm{m}^{-3}$ ): west industrial area and in the city's downtown. The other four stations met the country's standard: Venezuela has not updated the environmental regulations on air quality since 1995, and they do not include $\mathrm{PM}_{10}$ or $\mathrm{PM}_{2.5}$ (Morantes et al. 2016). Therefore, complying with Venezuelan environmental standards does not guarantee the protection of human 
health. For Maracaibo, the second most important city in that country, the TSP-annual concentrations between 2001 and 2008 remained above the Venezuelan regulation (between 75 and $200 \mu \mathrm{g} \mathrm{m}^{-3}$ ). TSP concentration level was related to the city's industrial park, vehicular traffic, soils devoid of vegetation, and buildings (Montes and Hurinson 2013). While for 2009 in the same town, $\mathrm{PM}_{2.5}$-annual $\left(36.2 \mu \mathrm{g} \mathrm{m}^{-3}\right)$ and $\mathrm{PM}_{10}$-annual $\left(80.8 \mu \mathrm{g} . \mathrm{m}^{-3}\right)$ were reported to exceed the then-current US EPA Standards, for $\mathrm{PM}_{2.5}$-annual (2009) and $\mathrm{PM}_{10}$-annual (1997) (Morales et al. 2012). In Valencia, in 1996, measured TSP in the rainy and dry seasons amounted to 75-200 $\mu \mathrm{g} \mathrm{m}^{-3}$ (Martínez 1997). These levels once again exceed the obsolete Venezuelan environmental standard. A PM dispersion modelling was developed for an industrial oil area in the northeast of the country. The authors concluded that under a conservative pollution scenario, people could live risk episodes for $\mathrm{PM}_{10}$ and $\mathrm{SO}_{2}$ (Rincón and Cremades 2012). These studies used data from more than 10 years ago; nonetheless, they revealed that the air quality in northern Venezuelan cities is compromised.

In the Boreal summer (period June-August), African dust storms generated in the Saharan Desert annually reach the American continent crossing the Atlantic and the Caribbean Sea (western Atlantic Ocean) (Euphrasie-Clotilde et al. 2021; Adams et al. 2012). During this period, there is a continuous alternation between African Easterly Waves and dust plumes. The most recently recorded event in June 2020 refers to an extremely intense dust plume dubbed "Godzilla" reaching the Atlantic Ocean (Euphrasie-Clotilde et al. 2021). Trapp et al. (2010) reported that Boreal summer is the maximum African dust transport season to Miami and Barbados. In the same lines, Engelstaedter et al. (2009) point out that the annual cycle of Sahara dust concentrations in Barbados reaches the seasonal maximum in April-August. Muhs et al. (2007) studied African dust inputs to soils of western Atlantic islands (Barbados, Bahamas, and Florida), being July the month with the most wind-transported dust from Africa. These authors and Prospero et al. (2014) hypothesise that African clouds of dust may be significant contributors to soils in northern South America (Cayenne, French Guiana and Guadeloupe, Lesser Antilles). Reid et al. (2003) also characterised African dust transported to Puerto Rico between June and July in 2000. Venezuela, located in the Tropical North Atlantic over the Caribbean, could also receive Saharan dust. However, according to the authors' knowledge, there are no known studies that inquire into the influence of African dust episodes in northern Venezuela.

Although particle size determines PM ability to penetrate the respiratory system, the chemical composition could accentuate its effects on mortality and morbidity: PM can be toxic, carcinogenic, mutagenic, and teratogenic due to the components in its mixture (Franklin et al. 2008; Atkinson et al. 2014; Apte et al. 2015; Wang et al. 2019).
Furthermore, PM composition is used for source appointment. Therefore, knowing the composition of particles is becoming essential in recent research. Scanning electron microscopy coupled with energy-dispersive spectrometry (SEM-EDX) is an instrumental technique that allows the characterisation via particles' morphological and elemental composition. Another method includes infrared spectroscopy (FTIR) that identifies the functional groups in PM. The authors had applied both techniques together to complement the findings of each independent analysis. SEM-EDX and FTIR have been used to propose the presence of plausible particle groups in mixtures of sampled aerosols (Ochsenkühn-Petropoulou et al. 2009; Bharti et al. 2017; Radulescu et al. 2017; Huda et al. 2018; Zeb et al. 2018).

In Venezuela, there are limited studies on particulate matter composition employing SEM-EDX and FTIR. However, other physicochemical techniques have been used. For a locality near Maracaibo (during rain and drought), García et al. (2002) analysed TSP particles by atomic absorption spectroscopy. They found $\mathrm{Pb}, \mathrm{V}, \mathrm{Ca}, \mathrm{Ni}, \mathrm{Fe}$, and $\mathrm{Mn}$ in the aerosols and associated them with emissions from a nearby cement factory and high vehicular traffic. $\mathrm{Mn}, \mathrm{Fe}$, and $\mathrm{Ca}$ were related to resuspended dust. They also highlighted the marked influence of the rain and drought on the concentration and composition of TSP. Machado et al. (2007, 2008) measured, in Maracaibo, the levels of metals $(\mathrm{Pb}, \mathrm{Ni}, \mathrm{Zn}$, $\mathrm{Cr}, \mathrm{Al}, \mathrm{Cu}, \mathrm{V}, \mathrm{Cd}$ ) in $\mathrm{PM}_{10}$ emitted from mobile sources sites with high vehicular density in rain and drought. These researchers found significant differences between the measurement sites and the climatic seasons in $\mathrm{PM}_{10}$ concentration and metals. Duque et al. (2010), near Maracaibo in 2008, evaluated $\mathrm{PM}_{10}$ using SEM-EDX in the dry and rainy seasons. They grouped the analysed particles based on $\mathrm{Si}, \mathrm{Si}-\mathrm{Al}$, $\mathrm{S}-\mathrm{Ca}, \mathrm{Cl}-\mathrm{Na}, \mathrm{Fe}, \mathrm{S}$, and $\mathrm{Cl}$ contents. Sources were related to soil and the marine environment. The authors found a significant difference between the elemental composition of the wet and dry periods. PM studies for Venezuela are not recent, and none has characterised aerosols in Caracas. Therefore, uncertainty remains about the PM characteristics in this city and about the possible presence of aerosols from other latitudes.

Morantes et al. (2019), in a study in the Sartenejas Valley (southeast of Greater Caracas), sampled different PM fractions between August 2014 and October 2015. The PM concentrations were influenced by forest fire events (drought in Sartenejas Valley) and the rains. However, the morphology and composition of PM were outside of the scope of that study.

Based on the influence of seasonality and Sahara storms over the composition and concentration of PM and the lack of knowledge about the physicochemical characterisation of PM in Venezuela, the objective of this research is to evaluate the morphology and the elemental chemical composition of 
particulate matter to establish possible sources of emission in an urban sector of Greater Caracas in Venezuela, during the rainy season between June and September 2018.

\section{Study area}

The Sartenejas Valley is located in Greater Caracas, in a continental area north of Venezuela (see Fig. A1 in Online Resource 1). It has an altitude between 1200 and $1400 \mathrm{~m}$ above sea level and occupies 230 ha. In the flat part of the Valley is a university campus that occupies about $95 \mathrm{ha}$, of which 45 are plantations with a high density of pine forest, native forest, secondary shrubland, and savanna with diverse shrubs. In the green areas surrounding the campus, forest fires frequently occur during the dry season, with haze episodes (Foghin-Pillin 2012, 2015). The central position of Venezuela in South America (in the middle of the northern intertropical zone, very close to the equator and open to the Caribbean Sea) means that it has an intertropical climate. Its climate is characterised by a rainy season (May-November) and a dry season (December-April). In Fig. A2_1 in Online Resource 1, the historical climogram (1970-2000) is shown with data from La Mariposa meteorological station administered by the National Institute of Meteorology and Hydrology (UTM coordinates $10.40417 ;-66.92500 \mathrm{~m}$ ) located $5.6 \mathrm{~km}$ from the Sartenejas Valley. This figure clearly shows the two seasons that characterise the region (rain and drought).

Socioeconomically, the Sartenejas Valley's surroundings show urban characteristics typical of Greater Caracas, where middle-class and upper-class urbanisations border with lowincome urbanisations. Country-wise, there is a trend towards a progressive increase in the population's concentration in the lower social strata (Ramirez 2012). In these strata, public services are scarce, which affects the waste management system's functioning, leading to improper burning of garbage, causing pollution and representing serious fire hazards (Ramos et al. 2012).

In this sector, people perceive good air quality despite there being a highway with high vehicular traffic at a distance of $2 \mathrm{~km}$ to the northwest (exit to the country's west). About $3.5 \mathrm{~km}$ to the southeast, there is an industrial-residential area. The Sartenejas Valley's surroundings have presented an accelerated urbanisation process that is causing high vehicular traffic and an increase in low-income settlements. The university campus dominates the urban landscape of the Valley.

\section{Methods}

\section{$P M_{2.5}$ sampling}

A PM collection campaign was carried out on the university campus at the Sartenejas Valley. The particulate material sampling station (AireUSB) was installed at the height of $9 \mathrm{~m}$; this height ensures that the air is representative of the sector (UTM coordinates, $10.412352 ;-66.883558 \mathrm{~m}$ ) (see Fig. A1 in Online Resource 1). Sampling for $\mathrm{PM}_{2.5}$ was carried out with a dichotomous air sampler (Partisol 2000i-D Dichotomous Air Samplers, THERMO Fischer Scientific, MA, US). The meteorological data was collected with Davis Instruments 2010 equipment, which operated $24 \mathrm{~h}$ a day during the sampling period. The variables controlled with this meteorological station were punctual measurements, and the nominal accuracy indicated on the equipment manual for each variable is the temperature $\left( \pm 3^{\circ} \mathrm{C}\right)$, the solar radiation $( \pm 5 \%)$, wind direction $\left( \pm 3^{\circ}\right)$, wind speed $\left( \pm 1 \mathrm{~m} \sim \mathrm{s}^{-1}\right)$, and precipitation $( \pm 0.02 \mathrm{~mm}$ ) (Davis Instruments, 2020).

The sampler operates by splitting PM sample streams into a fine and a coarse fraction using a virtual impactor. Samplers are typically characterised by their cut point, which defines the particle size for which the penetration is $50 \%$ (the cut point $D_{50}$ ). The partisol operates at a flow rate of $15.0 \mathrm{~L} \mathrm{~min}^{-1}$ to provide a $D_{50}$ at $2.5 \mu \mathrm{m}$ (Loo and Cork 1988; Thermo Fisher Scientific 2011). PTFE membrane filters (polytetrafluoroethylene, known as Teflon- $\mathrm{CF}_{2}$ ) of 2- $\mu \mathrm{m}$ pore were used (46.2 $\mathrm{mm}$ in diameter with a support ring). The samples were put in aluminium foil, sealed with a plastic cover, and stored in a refrigerator until further analysis.

The sampling campaign was carried out between June 30th and July 23rd, 2018 (S1-S7 samples) and September 17th-October 6th, 2018 (S8-S13 samples). The period includes the Boreal summer and avoids the season of local forest fires. Samples were collected twice a week for sampling times of $48 \mathrm{~h}$ (Saturday-Sunday; i.e. weekends) and $100 \mathrm{~h}$ (Monday-Friday; i.e. during the week) for a total of thirteen samples: one sample (S12—01/10/2018) was discarded due to contamination during handling for physicochemical analysis. No samples were ruled out due to rain. Thus, the overall account of samples in this study comes to 12 samples. The sampling times were chosen to secure the necessary weight in the filters following a previous sampling in the Valley Sartenejas (Morantes et al. 2019).

Fig A2_2 in Online Resource 1 shows meteorology variables during the sampling period. Fig. A2_2 (b) presents the temperature and precipitation in the Sarteneja Valley; the figure shows the dates of greatest precipitation (S909/22/2018: $24.10 \mathrm{~mm}$ and S10—09/24/2018: $9.00 \mathrm{~mm}$ ), which coincide with the dates of highest temperature (S8-09/18/2018: $25.1^{\circ} \mathrm{C}$ and S9-09/22/2018: $23.5{ }^{\circ} \mathrm{C}$ ). Fig. A2_2 (c) shows that the predominant wind directions were East-Northeast and Northeast, with a predominant speed lower than $8.12 \mathrm{~m} \mathrm{~s}^{-1} \pm 1 \mathrm{~m} \mathrm{~s}^{-1}$ and $35 \%$ calm winds. From the table shown in Fig. A2_2 (a), the average monthly temperature in the Sartenejas Valley remained between 17.9 and $25.1{ }^{\circ} \mathrm{C}\left(T_{\text {average }} \sim 19.4 \pm 2.2{ }^{\circ} \mathrm{C}\right)$; the relative humidity varied between 85.3 and $98.0 \%\left(H r_{\text {average }} \sim 88.5 \pm 3.4 \%\right)$; 
average wind speed was $\sim 2.50 \pm 1.2 \mathrm{~m} \mathrm{~s}^{-1}\left(0.00-8.12 \mathrm{~m} \mathrm{~s}^{-1}\right)$, with 5 samples recording no rainfall and 7 samples with accumulated rainfall between 1.76 and $24.10 \pm 0.2 \mathrm{~mm}$.

\section{Analytical techniques}

\section{FTIR spectroscopic analysis}

Teflon filters were analysed by Fourier transform infrared spectroscopy-attenuated total reflectance (ATR-FTIR). Filters were scanned 200 times at $4 \mathrm{~cm}^{-1}$ resolution, producing an infrared absorbance spectrum from 600 to $4000 \mathrm{~cm}^{-1}$. Twelve samples (plus two filter blanks) were directly analysed by FTIR spectroscopy using Thermo Nicolet equipment, model iS5 with ZnSe crystal. A blank filter spectrum was analysed to identify its characteristic signals and obtain the final sample's spectrum.

Each spectrum was subsequently normalised to the highest characteristic signal of the Teflon filter. Each spectrum was taken in triplicate. The magnitude in the intensity of the signals was measured from the baseline. The pre-scan spectrum was subtracted from the post-scan spectrum using software Omnic 7.3 (Thermo Nicolet) and software Spectragryph 1.2. A mark was established on the filter holder to ensure that the orientation of each filter was constant.

\section{SEM-EDX analysis}

The scanning electron microscopy (SEM) analysis was carried out with the help of a computer-controlled scanning electron microscope (JEOL model JSM6390) coupled with an energy-dispersive spectroscopy (EDX) (Inca software). The SEM working conditions were set at an accelerating voltage of $30 \mathrm{kV}$. The images were recorded at two different magnifications, $1000 \times$ and $500 \times$.

Sections of $\sim 2 \mathrm{~cm}^{2}$ of filters were cut for SEM-EDX samples. With a vacuum unit's help, a skinny layer of gold ( $\mathrm{Au})$ was put over each sample surface to achieve better conductivity and reduce electron charge. The sputter can prepare six samples simultaneously. Microscope magnifications of 100 , 50,20 , and $10 \mu \mathrm{m}$ were used. About fifteen random particles were selected on each field filter, giving approximately fifteen manually characterised particles per filter. The EDX spectra of blank filters were also measured and subtracted from the samples (see Fig. A3 in Online Resource 3).

The blank filter's elemental composition showed an approximate $1 \mathrm{C}: 2 \mathrm{~F}$ ratio and was coated in gold. The contributions of $\mathrm{C}, \mathrm{F}$, and Au were manually subtracted during the EDX spectrum evaluation. The weight percent of each element present in the spectrum was identified and normalised to $100 \% \mathrm{wt}$.

\section{PM physicochemical characterisation}

Sampled PM filters were divided into two sections: one was analysed by Fourier transform infrared spectroscopy (FTIR) to identify the functional groups present in particulate material (non-individual particulate analysis). Scanning electron microscopy (SEM) was used to analyse the other section of the filter to know the particles' morphology and elemental composition (individual particle analysis).

FTIR was used to identify the possible sources of emission of the PM; for this, characteristic signals were identified for the specific functional groups through their frequencies. Sources were assigned through an exhaustive literature review of previous research on spectroscopy of atmospheric aerosols. Like other authors, we try to relate functionality identified in airborne PM with its possible origin: Cunningham et al. (1974); Allen et al. (1994); Blando et al. (1998); Maria et al. (2002, 2003); Shaka' and Saliba (2004); Reff et al. (2005); Senthil and Rajkumar (2013); Saikia et al. (2016).

The SEM-EDX analysis provides information to design clustering rules of the particles, through which categories, groups and subgroups of particles with similarities will be identified, taking into account (i) the elements found and their \%wt; (ii) morphology; and (iii) bibliographic review to identify similarities based on the experience of the following authors: Matthias-Maser and Jaenicke (1991, 1994); US-EPA (2002); Gao et al. (2007); Kandler et al. (2007); Vester et al. (2007); Cong et al. (2009); Campos-Ramos et al. (2010); Coz et al. (2010); Pachauri et al. (2013); Geng et al. (2014); Mico et al. (2015); Durdziński et al. (2015); Zeb et al. (2018); Eriksen Hammer et al. (2018). In addition, clustering rules allow us to assign possible sources of origin. Thus, both techniques together (FTIR and SEM-EDX) complement the particles' qualitative recognition information.

\section{Saharan dust influence}

To study the Saharan dust influence over the PM samples, we separated them according to the Boreal summer months into S1-S7 (July) and S8-S13 (September). FTIR signals are qualitatively analysed to detect possible differences between samples. A quantitative analysis is performed using the Student t-test and Mann-Whitney $U$ test for mean differences. The Pearson correlation coefficient is used for assessing relationships among variables.

\section{PM quantitative source appointment}

Principal component analysis (PCA) and hierarchical cluster analysis (HCA) have been widely used in the study of 
particulate matter for identifying the relationships between particles and their sources (Chavent et al. 2009; Kothai et al. 2011; Genga et al. 2012; Tsitouridou et al. 2013; Błaszczak 2018). The elemental composition of particles (\%wt) obtained with SEM-EDX was used for source appointment applying PCA and HCA. Varimax rotation was used as the rotation method for PCA through the Spearman correlation. Likewise, HCA was used for comparing the results obtained from the PCA. XISTAT statistical software was used.

\section{Results and discussion}

\section{FTIR spectroscopic analysis}

FTIR spectra showed numerous signals assigned to organic and inorganic functional groups such as carbonyls, aliphatic $\mathrm{C}-\mathrm{H}$ bonds, hydroxyls, silicates, and nitrates. The blank PTFE filter spectrum (see Fig. A4 in Online Resource 1) presented two intense bands in the region of $1000-1300 \mathrm{~cm}^{-1}$ associated with the stretching of the $\mathrm{C}-\mathrm{F}$ bonds, as well as two signals of less intensity around $640 \mathrm{~cm}^{-1}$. Additionally, it exhibited a pair of signals in the $2800-3000 \mathrm{~cm}^{-1}$ range corresponding to the saturated $\mathrm{C}-\mathrm{H}$ bonds.
Figures 1 and 2 show the FTIR spectra taken for weekends $(48 \mathrm{~h})$ and during the week $(100 \mathrm{~h})$, respectively. Samples taken for 48 and $100 \mathrm{~h}$ had similar spectra trends, revealing that anthropogenic activity does not change during the week and on weekends. Furthermore, samples taken for $100 \mathrm{~h}$ accumulated more mass resulting in higher FTIR absorption intensities (see Fig. A5 in Online Resource 1). Table 1 shows the functional groups identified by ATR-FTIR.

At different intensities, most spectra showed an absorption band located at $1031 \mathrm{~cm}^{-1}$, attributed to the asymmetric stretching of the $\mathrm{O}-\mathrm{Si}-\mathrm{O}$ bonds in the silicate ion $\mathrm{SiO}_{4}{ }^{-}$(Allen et al. 1994; Maria et al. 2002, 2003; Shaka' and Saliba 2004). This ion also exhibits weaker absorptions at 780 and $800 \mathrm{~cm}^{-1}$ due to the $\mathrm{O}-\mathrm{Si}-\mathrm{O}$ bond's deformation vibration (Cunningham et al. 1974; Shaka' and Saliba 2004). The silicate minerals (like quartz) are considered major inorganic constituents of particulate matter (Senthil and Rajkumar 2013). The signal observed around $1006 \mathrm{~cm}^{-1}$ corresponds to the $\mathrm{Si}-\mathrm{O}$ stretches associated with aluminosilicates such as kaolinite $\left[\mathrm{Al}_{2}(\mathrm{OH})_{4}\left(\mathrm{Si}_{2} \mathrm{O}_{5}\right)\right]$. Kaolinite has been found in PM samples and coarse fractions (Senthil and Rajkumar 2013; Reff et al. 2005). The absorption bands in the range $3500-3750 \mathrm{~cm}^{-1}$ are also characteristic of kaolinite due to OH's stretching vibrations in the mineral structure (Saikia and Parthasarathy 2010). The absorptions

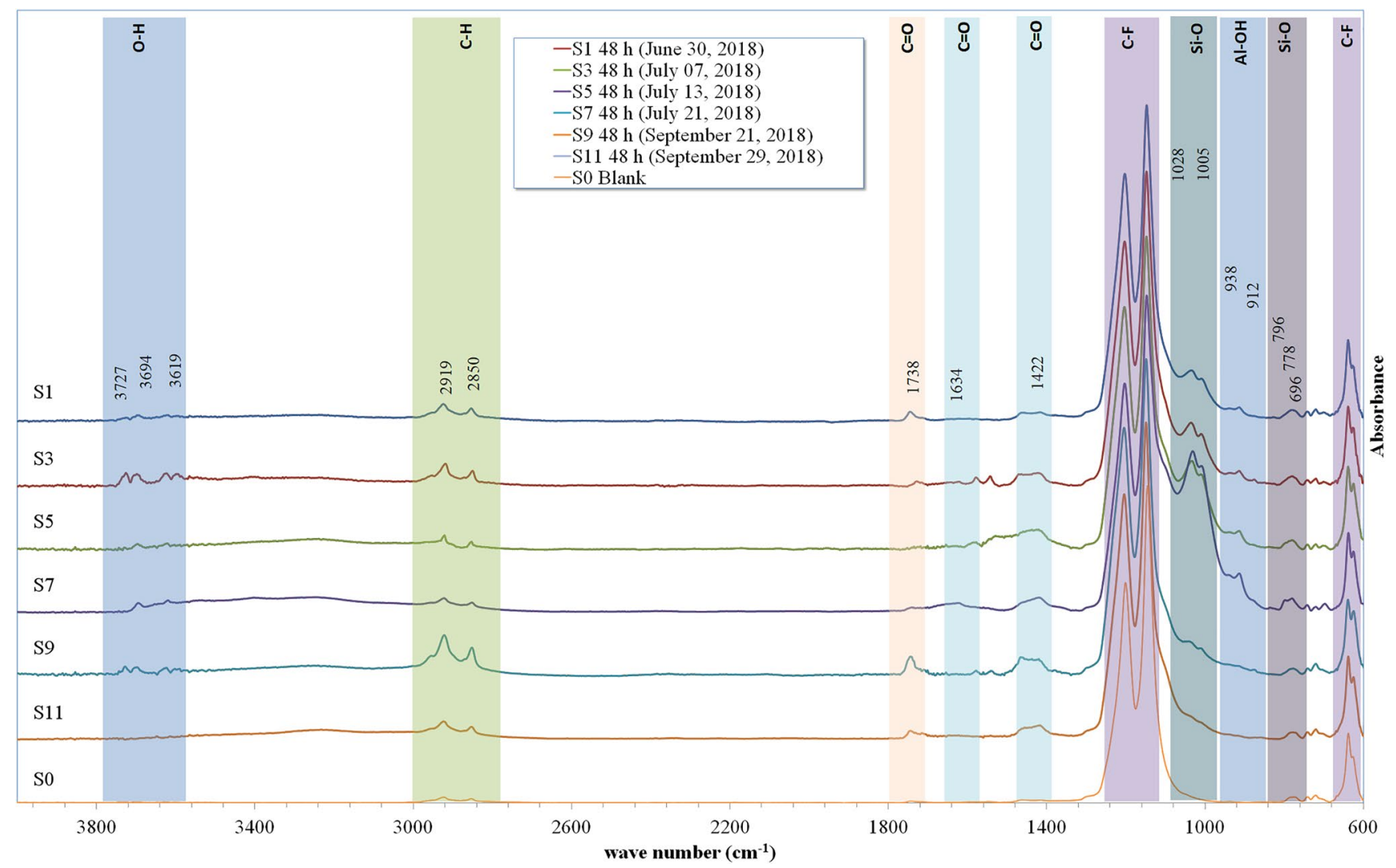

Fig. 1 FTIR spectra: collection period $48 \mathrm{~h}$ 


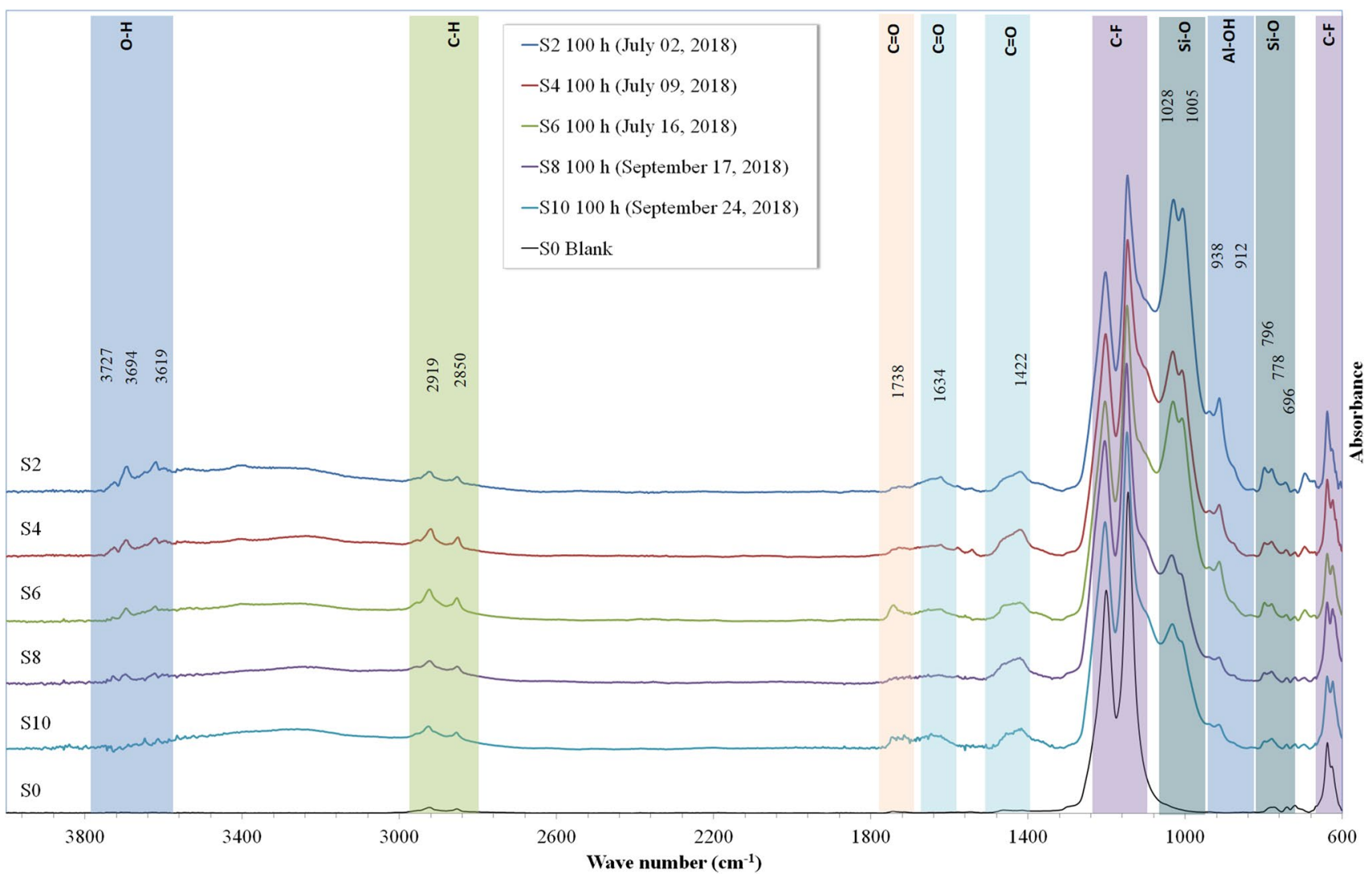

Fig. 2 FTIR spectra: collection period 100h

around $940-914 \mathrm{~cm}^{-1}$ can be associated with vibrations of hydroxyls and the $\mathrm{Al}-(\mathrm{OH})$ bond of kaolinite, respectively (Shaka' and Saliba 2004; Saikia and Parthasarathy 2010; Senthil and Rajkumar 2013; Anıl et al. 2014).

The signals in the range $2850-3000 \mathrm{~cm}^{-1}$ are characteristic of aliphatic hydrocarbons due to the symmetric and asymmetric stretching of the methyl $\left(\mathrm{CH}_{3}\right)$ and methylene $\left(\mathrm{CH}_{2}\right)$ groups. They are represented by a pair of peaks around 2924 and $2853 \mathrm{~cm}^{-1}$ (Allen et al. 1994; Maria et al. 2002; Shaka' and Saliba 2004; Reff et al. 2005).

The vibrations observed in $1720-1760 \mathrm{~cm}^{-1}$ are attributed to the carbonyl functional group present in aldehydes, ketones, and carboxylic acids. Its absorption is reported in the range $1640-1850 \mathrm{~cm}^{-1}$, generally reaching a maximum in 1714-1720 $\mathrm{cm}^{-1}$ (Allen et al. 1994; Reff et al. 2005; Coury and Dillner 2009).

The possible presence of nitrogen compounds was detected, such as aliphatic nitro groups that absorb more strongly around $1540-1570 \mathrm{~cm}^{-1}$. The aromatic nitro groups were observed in the band $1500-1530 \mathrm{~cm}^{-1}$ (Akhter et al. 1984; Allen et al. 1994; Weakley et al. 2016). Ammonium salts' absorptions are strong in the range of $1250-1540 \mathrm{~cm}^{-1}$, with peaks between 1410 and $1435 \mathrm{~cm}^{-1}$ (Allen et al. 1994). In the samples, these salts were detected between 1417 and
$1422 \mathrm{~cm}^{-1}$. Another signal was also seen in $825-835 \mathrm{~cm}^{-1}$, which corresponds to the absorption of the nitrate ion (Allen et al. 1994; Reff et al. 2005): nitrate ion is formed from the photo-oxidation of nitrogen oxides (NOx) and is related to vehicle emissions (Senthil and Rajkumar 2013; Ji et al. 2015).

Seinfeld and Pandis (2016) reported sulfates $\left(\mathrm{SO}_{4}{ }^{-2}\right)$ in atmospheric aerosols formed from the photo-oxidation of sulfur dioxide. This ion is absorbed in the ranges 612-618 $\mathrm{cm}^{-1}$ and $1103-1135 \mathrm{~cm}^{-1}$ (Allen et al. 1994; Blando et al. 1998; Maria et al. 2002, 2003; Yu et al. 2018). The absorptions in both ranges could not be fully identified in this investigation because of the overlapping of the Teflon filter signals; however, an interference was identified to the signal's right at $1145 \mathrm{~cm}^{-1}$ of C-F bond of the Teflon, which could correspond to the $1100 \mathrm{~cm}^{-1}$ sulfate signal.

\section{SEM-EDX analysis}

We analysed two hundred airborne particles from twelve samples collected by SEM-EDX. From this analysis, it was established that the particles contain different elements. Therefore, to analyse the PM, they are categorised as geogenic, metallic, C-rich, and secondary aerosols; in 
Table 1 Functional groups identified by ATR-FTIR

\begin{tabular}{|c|c|c|c|c|}
\hline $\begin{array}{l}\text { Frequency } \\
\text { Range } \\
\left(\mathrm{cm}^{-1)}\right.\end{array}$ & Mode of Vibration & Functionality & Possible source(s) & Ref \\
\hline 3750-3995 & Stretching $-\mathrm{OH}$ & Kaolinite & Soil related & $\begin{array}{l}\text { Senthil and Rajkumar (2013); Saikia } \\
\text { et al. (2016) }\end{array}$ \\
\hline $3670-3650$ & Stretching $-\mathrm{OH}$ & Kaolinite & & $\begin{array}{l}\text { Senthil and Rajkumar (2013); Saikia } \\
\text { et al. (2016) }\end{array}$ \\
\hline $3500-3300$ & Stretching $-\mathrm{OH}$ & Alcohol and humidity & Ambient humidity; mineral particles & Allen et al. (1994); Reff et al. (2005) \\
\hline $2970-2850$ & Stretching $\mathrm{C}-\mathrm{H}$ & H. aliphatic $\left(\mathrm{CH}_{\mathrm{x}}\right.$ Saturated $)$ & Ambient humidity; mineral particles & Allen et al. (1994); Maria et al. (2003) \\
\hline $1850-1640$ & Stretching $\mathrm{C}=\mathrm{O}$ & Carbonyl & Combustion of fuel & Allen et al. (1994); Maria et al. (2003) \\
\hline 1636 & Stretching $\mathrm{C}=\mathrm{O}$ & Carbonate & & Senthil and Rajkumar (2013) \\
\hline$\sim 1623$ & Deformation $-\mathrm{OH}$ & Kaolinite & Soil related & $\begin{array}{l}\text { Senthil and Rajkumar (2013); Saikia } \\
\text { et al. (2016) }\end{array}$ \\
\hline $1570-1540$ & $\mathrm{R}-\mathrm{NO}_{2}$ & Aliphatic nitro groups & Vehicle emissions & Allen et al. (1994) \\
\hline $1530-1540$ & $\mathrm{NH}_{4}^{+}$ & Ammonium ion & & $\begin{array}{l}\text { Allen et al. (1994); Shaka' and Saliba } \\
\text { (2004) }\end{array}$ \\
\hline 1422 & Stretching $\mathrm{C}=\mathrm{O}$ & Carbonate & Combustion of fuel & Senthil and Rajkumar (2013) \\
\hline 1431 & Stretching $\left(\mathrm{CO}_{3}\right)_{2}^{-}$ & Carbonate & & Senthil and Rajkumar (2013) \\
\hline$\sim 1030$ & Stretching $\mathrm{Si}-\mathrm{O}$ & Quartz/Kaolinite & Soil related & $\begin{array}{l}\text { Cunningham et al. (1974); Maria et al. } \\
\text { (2002, 2003); Senthil and Rajkumar } \\
\text { (2013); Saikia et al. (2016) }\end{array}$ \\
\hline$\sim 1006$ & Stretching $\mathrm{Si}-\mathrm{O}$ & Aluminosilicate & & Senthil and Rajkumar (2013) \\
\hline$\sim 938$ & Deformation Al-OH & Kaolinite & & $\begin{array}{l}\text { Senthil and Rajkumar (2013); Saikia } \\
\text { et al. (2016) }\end{array}$ \\
\hline$\sim 913$ & Deformation Al-OH & Kaolinite & & $\begin{array}{l}\text { Senthil and Rajkumar (2013); Saikia } \\
\text { et al. (2016) }\end{array}$ \\
\hline $825-835$ & $\mathrm{NO}_{3}^{-}$ & Nitrates & Vehicle emissions & Allen et al. (1994); Blando et al. (1998) \\
\hline$\sim 797$ & Bending $\mathrm{Si}-\mathrm{O}$ & Quartz/Kaolinite & Soil related & $\begin{array}{l}\text { Cunningham et al. (1974); Maria et al. } \\
\text { (2002, 2003); Senthil and Rajkumar } \\
\text { (2013); Saikia et al. (2016) }\end{array}$ \\
\hline$\sim 778$ & Stretching $\mathrm{Si}-\mathrm{O}$ & Quartz & & $\begin{array}{l}\text { Senthil and Rajkumar (2013); Saikia } \\
\text { et al. (2016) }\end{array}$ \\
\hline$\sim 745$ & Stretching Al-O-Si & Kaolinite & & Saikia et al. (2016) \\
\hline$\sim 718$ & Stretching $\mathrm{Fe}-\mathrm{O}$ & Magnetite & & Senthil and Rajkumar (2013) \\
\hline$\sim 696$ & Stretching $\mathrm{Si}-\mathrm{O}$ & Quartz & & Saikia et al. (2016) \\
\hline
\end{tabular}

turn, the various categories were organised into groups and subgroups/possible compounds (see Fig. 3).

A visual scan of the SEM-EDX images of the filters showed a high presence of particles with $D p>2.5 \mu \mathrm{m}$. Claiborn et al. (2000), in their study, found that in dust storm transport events, $\mathrm{PM}_{2.5}$ correlates more favourably with $\mathrm{PM}_{10}$ than with finer fractions $\left(\mathrm{PM}_{1}\right)$. On the other hand, Wagner and Casuccio (2014), in a study of urban desert regions in the USA, showed that in the filters with greater accumulation of mass, there were a significant number of large particles; the particles of the $\mathrm{PM}_{2.5}$ filter had diameters of up to $15 \mu \mathrm{m}$. Likewise, Wagner et al. (2019) associated the presence of coarse particles with re-dragging and the action of strong winds. We detected an abundance of large particles in the PM filters, especially for July's samples, resulting from dust transport events that reached the sampling area on those dates. For the SEM-EDX analysis, particles were chosen at random regardless of their size.

The most abundant elements were $\mathrm{C}, \mathrm{O}$, and $\mathrm{Si}$, and the least abundant were $\mathrm{Ca}, \mathrm{Al}, \mathrm{Mg}, \mathrm{S}, \mathrm{Cl}, \mathrm{Fe}, \mathrm{K}$, and Ti. Based on the bibliographic review on elemental composition, clustering rules, and morphology, the particles were classified in this investigation, as shown in Table 2. This table lists particles organised according to the relative abundance, possible compounds, clustering rules, the average elemental composition of each group/subgroup, and their morphology. Figure 4 shows the SEM photomicrographs representatives of all particle groups.

1) Geogenic particles' category (relative abundance $52.05 \%$ ) 


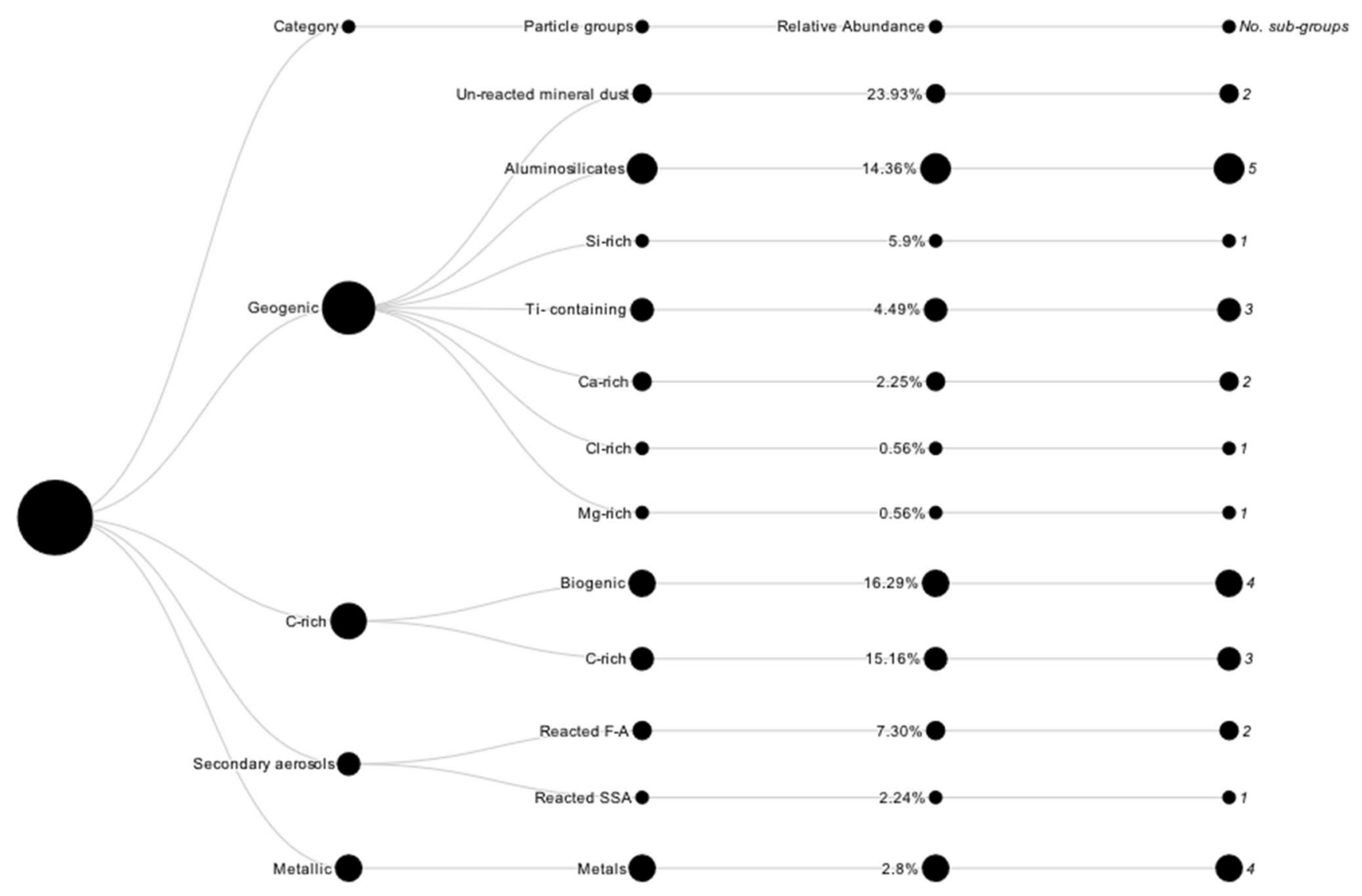

Fig. 3 Overview of categorisation used for particles

Geogenic particles are natural or minerogenic of crustal origin. Elemental analysis has revealed particles containing at least one of the following elements: $\mathrm{Na}, \mathrm{Mg}, \mathrm{Al}, \mathrm{Si}$, $\mathrm{Cl}, \mathrm{K}, \mathrm{Ca}$, and $\mathrm{Fe}$, which are soil derived (mineral dust). The geogenic category has the highest relative abundance, indicating local and transported dust dominance. This group comprises unreacted mineral dust, aluminosilicates, Si-rich, Ti-containing, Ca-rich, Cl-rich, and Mg-rich particles.

1.1) Unreacted mineral dust group (Fe-mixture) (relative abundance $23.93 \%$ )

A mixture of aluminosilicate particles with iron, magnesium, and/or sodium and other soil-related compounds was observed. Particles containing $\mathrm{Al}-\mathrm{Si}-\mathrm{O}-\mathrm{Fe}$ as major elements (\%wt) plus $\mathrm{Mg}$ and/or $\mathrm{Na}$ were classified as per the clustering rules shown in Table 2. These are unreacted mineral dust or mixtures of aluminosilicate particles with other crustal elements such as $\mathrm{Fe}, \mathrm{K}, \mathrm{Ca}$, $\mathrm{Na}$, and $\mathrm{Mg}$, originating from the earth. This type of dust is mixed with various inorganic materials making their compositions complicated. Other authors have also characterised these Fe-mixtures with analytical techniques (i.e. EDX, XRD, XAFS) and morphology characteristics (Geng et al. 2014; Mico et al. 2015; Boev et al. 2013;
Jung et al. 2012; Campos et al. 2009; Fišák et al. 2012; Cvetković et al. 2012; Huang et al. 2018).

This group is divided into five subgroups: one containing only $\mathrm{Mg}-\mathrm{Fe}$ (iron-magnesium aluminosilicates), and another containing $\mathrm{Mg}$-Fe plus other elements (montmorillonite or $\mathrm{Mg}$-vermiculite). Fe and $\mathrm{Mg}$ correlate at $r=0.823(p=0.01)$ for both subgroups, which allow for differentiating these particles from others. Furthermore, this type of particles is related to dust resuspension; therefore, wind could have played an essential role in the heterogeneous mixing process of mineral dust.

Other unreacted mineral dust particles contained combinations of Fe-Na and K-Cl-Ca-Mg. These particles were classified into three subgroups based on their elemental composition and/or particular morphology (see Table 2). The Al-Si-O-Fe-Na subgroup's morphology tended to go from round to sharp when $\mathrm{NaCl}$ $\%$ wt increased in the mix, indicating that the $\mathrm{NaCl}$ particles came from various sources. The varying amounts of $\mathrm{NaCl}$ can result from mixing mechanisms in the air, including particle-to-particle collisions and coagulation of mineral dust with Cl-rich aerosols.ww $\mathrm{Na}$ and $\mathrm{Cl}$ correlate $(r=0.498 ; p=0.01)$ in one of the unre- 


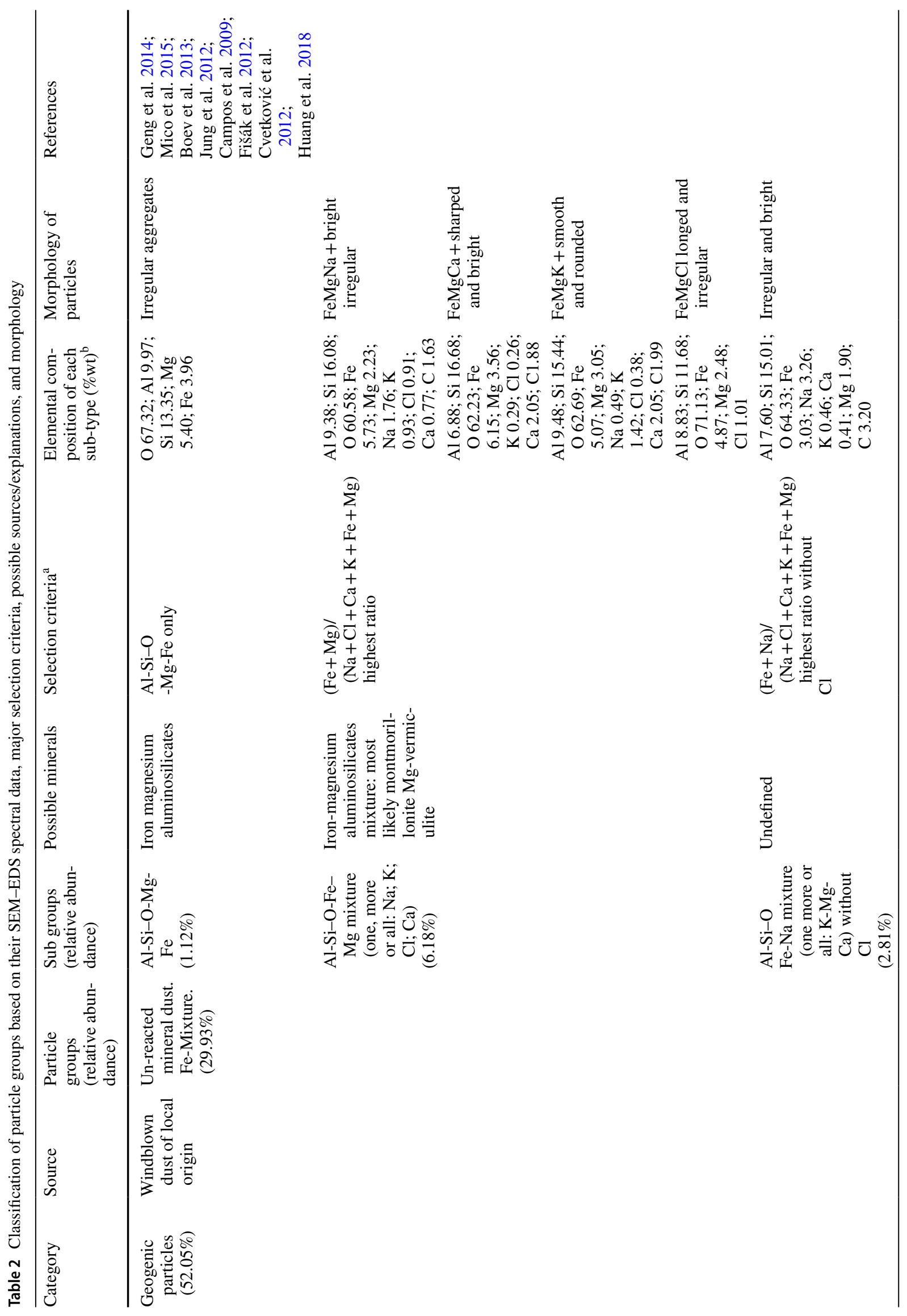




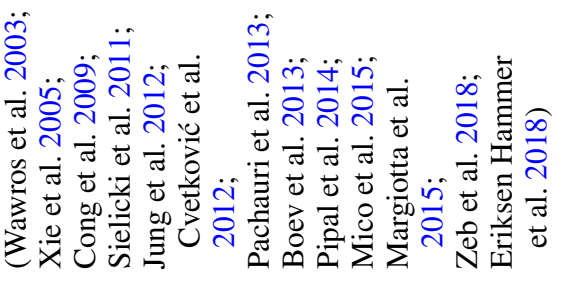

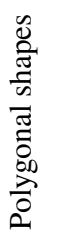
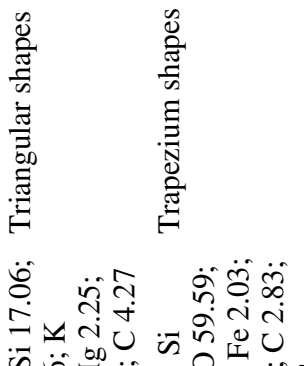

च

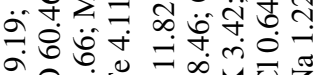

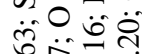
守 的家

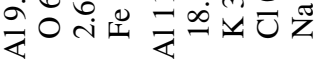
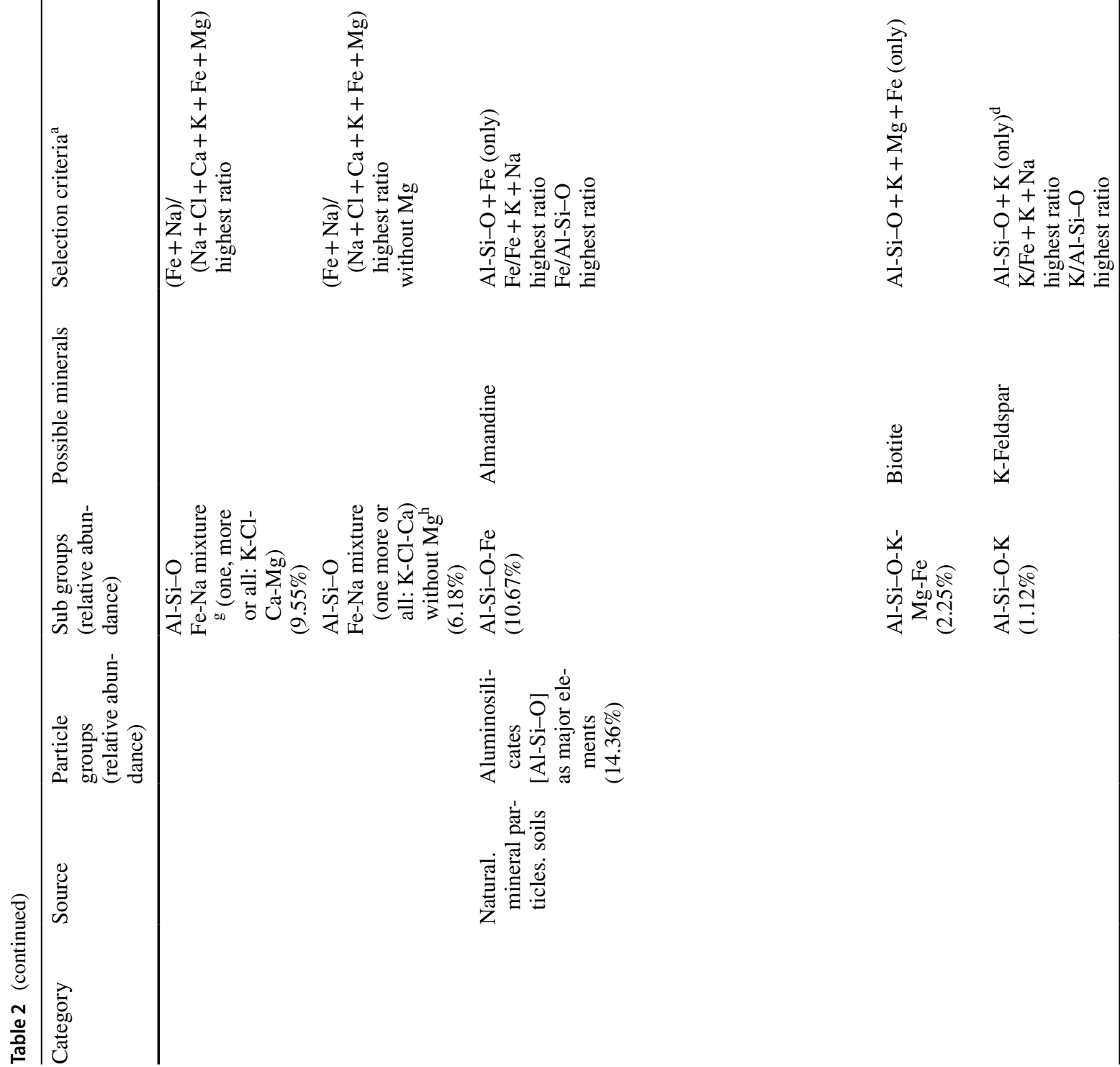


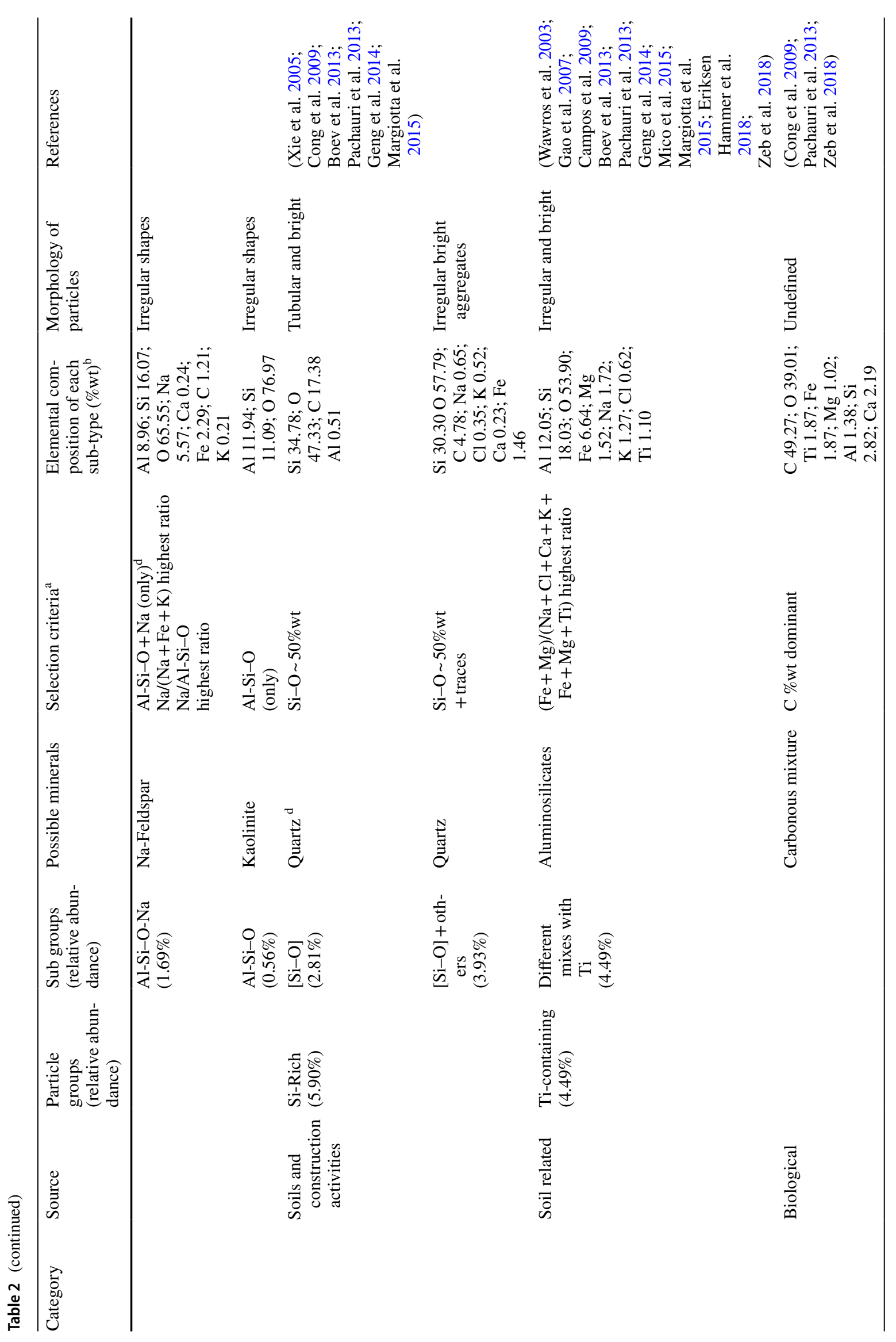




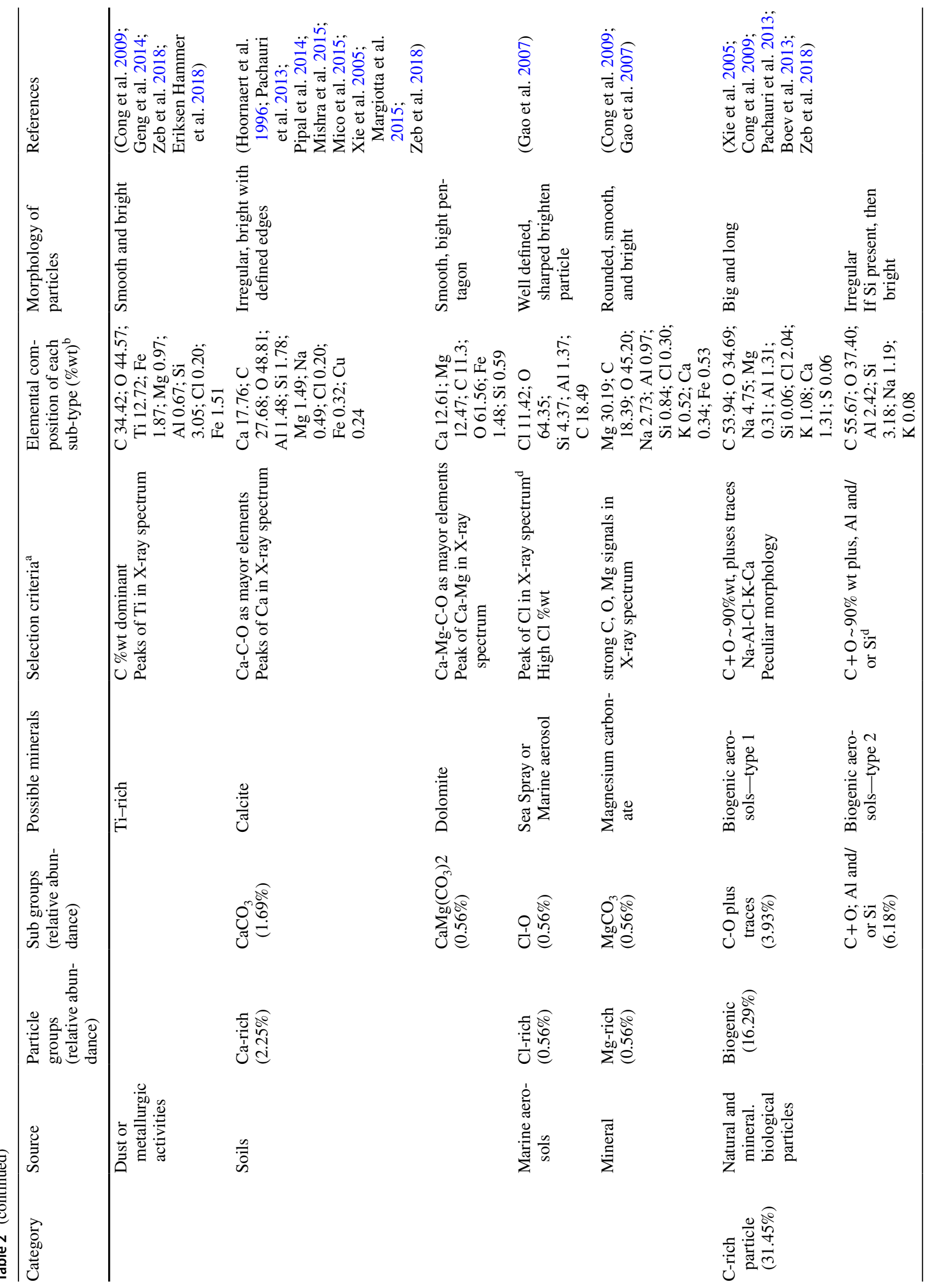




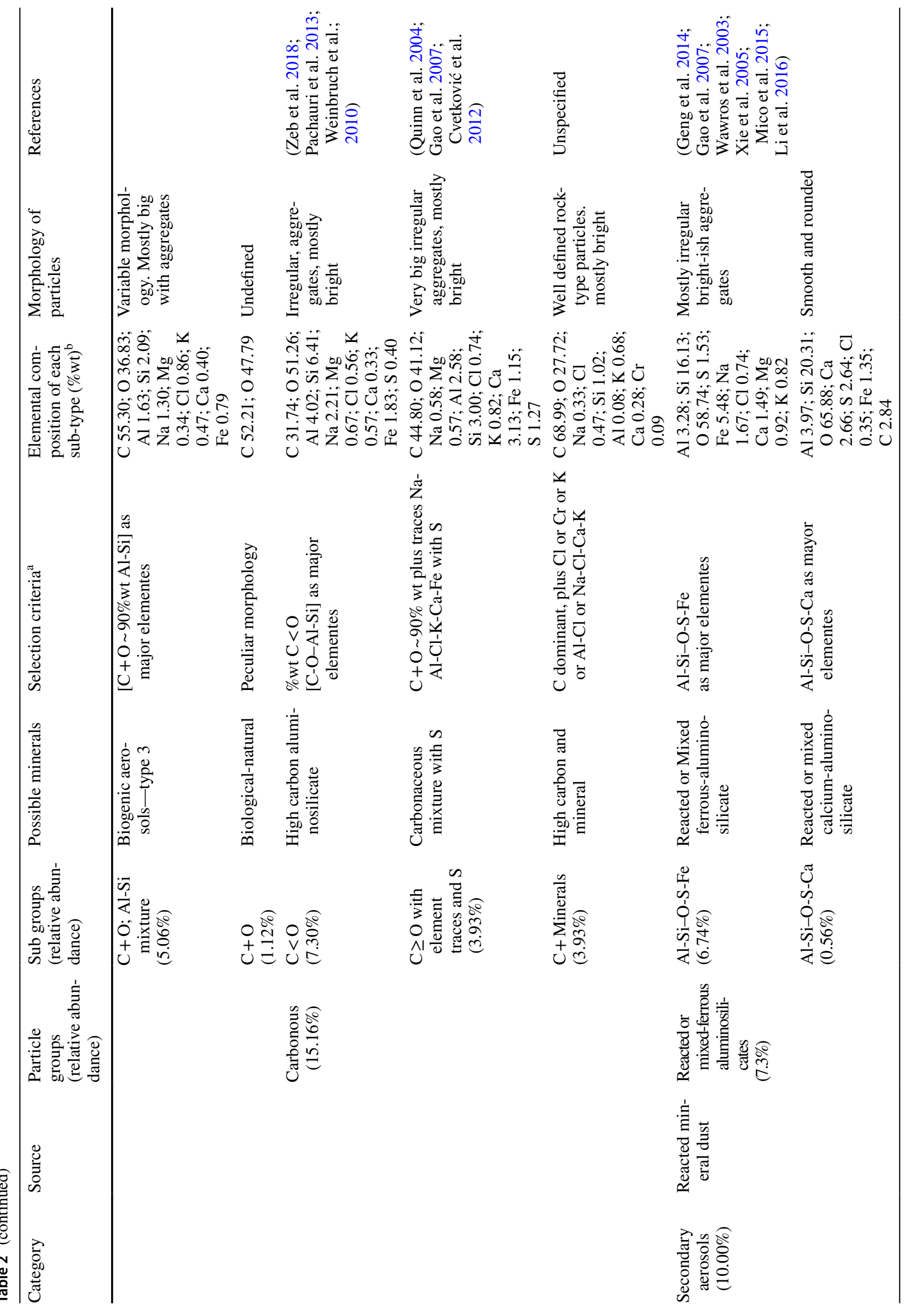




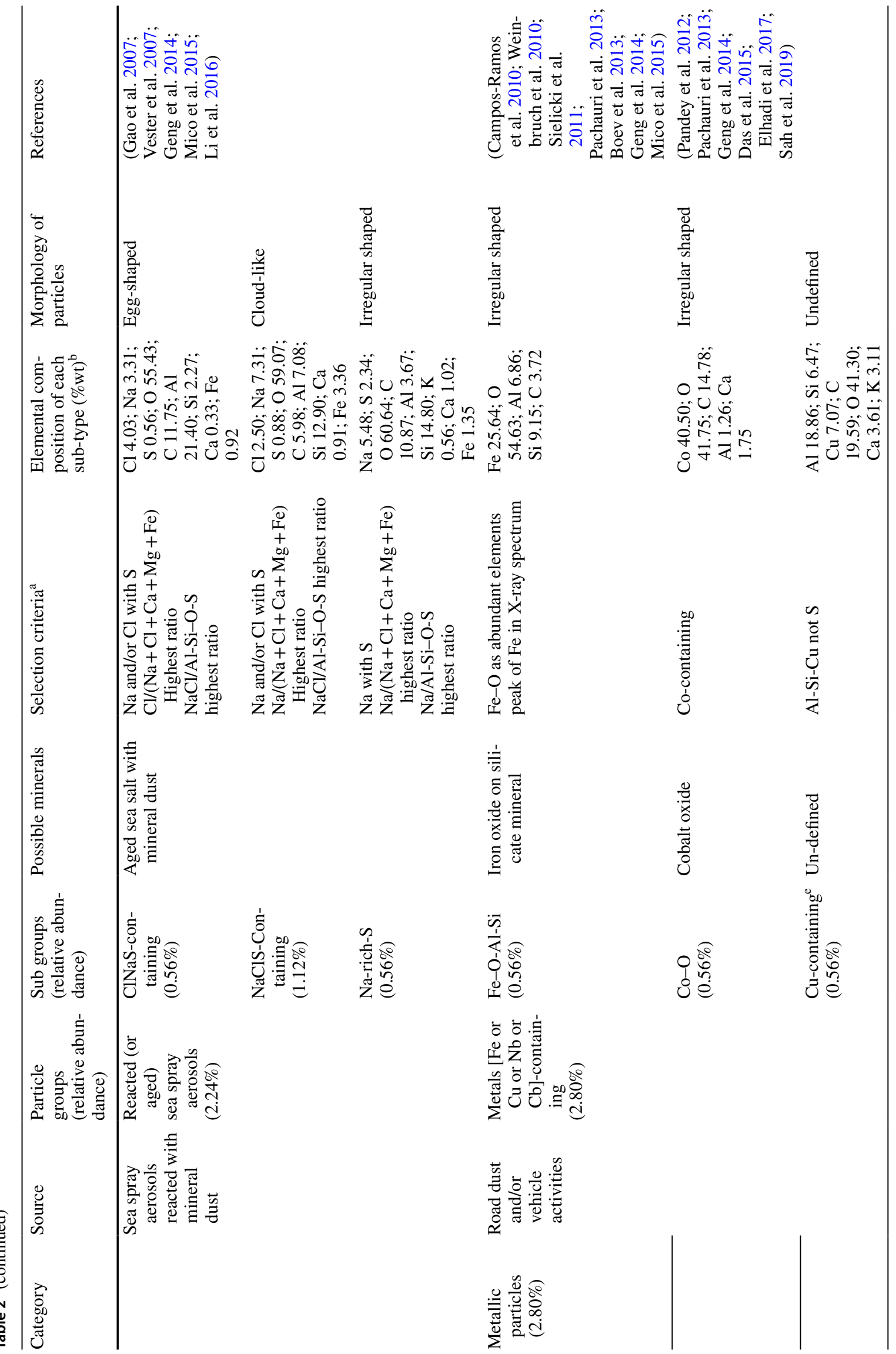




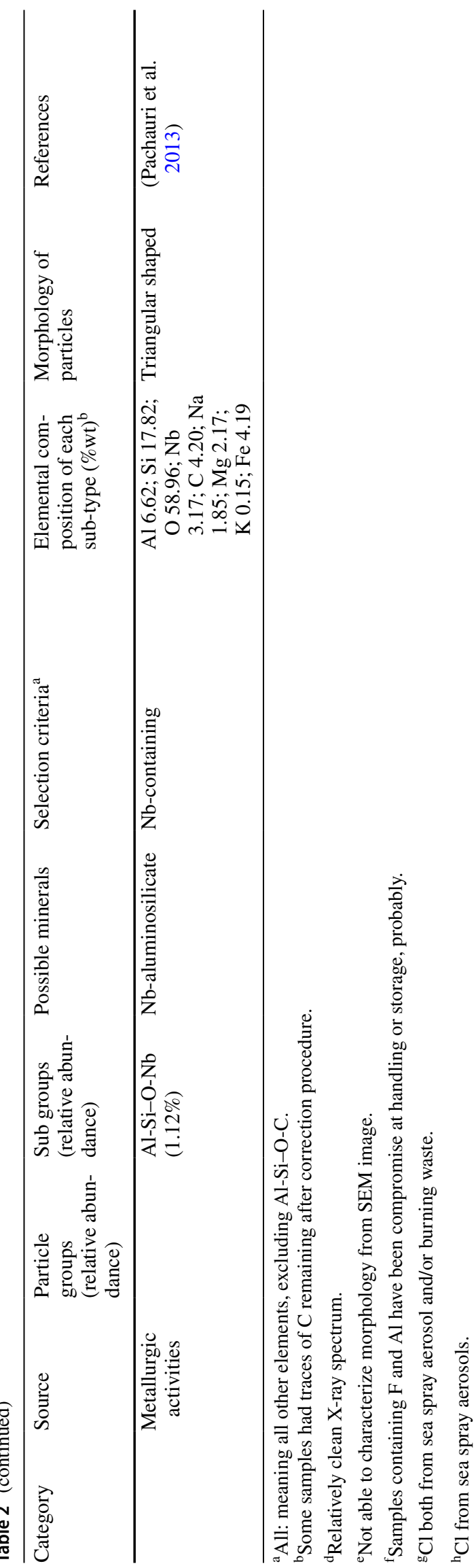


acted mineral dust subgroups, indicating $\mathrm{NaCl}$ particles' presence in the sampling site. In this subgroup, irregular aggregates are the predominant morphology. Figure $4 \mathrm{a}$ is an example of unreacted mineral dust (Fe-mixture without $\mathrm{Cl}$ ).

1.2) Aluminosilicate group (relative abundance 14.36\%) Aluminosilicate particles have $\mathrm{Al}-\mathrm{Si}-\mathrm{O}$ as major elements (\%wt) with varying amounts of $\mathrm{K}-\mathrm{Mg}-\mathrm{Fe}-\mathrm{Na}$. Different kinds of aluminosilicates are proposed as subgroups like almandine, biotite, Na-feldspar, K-feldspar, and kaolinite, belonging to clay minerals. The most common source of these particles is the crustal origin. However, dust is the dominant source of aluminosilicates due to eolian dispersion of soil particles or from resuspension of road dust caused by vehicles.

The size of aluminosilicate particles varied but is mainly $D p>2.5 \mu \mathrm{m}$. Particle shapes in this group are polygonal (almandine), triangular (biotite), trapezium (K-feldspar), and irregular shapes (Na-feldspar and kaolinite) (Table 2). Figure $4 \mathrm{~b}$ presents an example of aluminosilicates (biotite).

$\mathrm{Al}-\mathrm{Si}-\mathrm{O}$ particles have two origins: natural (irregularly shaped) and anthropogenic (fly ash with spherical shapes). From the morphologies found in the aluminosilicates of this study, we can suggest that they are soil derived (Wawros et al. 2003; Xie et al. 2005; Cong et al. 2009; Sielicki et al. 2011; Jung et al. 2012; Cvetković et al. 2012; Pachauri et al. 2013; Boev et al. 2013; Pipal et al. 2014; Mico et al. 2015; Margiotta et al. 2015; Zeb et al. 2018; Eriksen Hammer et al. 2018).

1.3) Si-rich group (relative abundance 5.90\%)

Particles containing predominantly silicon are classified as quartz $\left(\mathrm{SiO}_{2}\right)$. These are identified by having pronounced peaks of $\mathrm{Si}$ in the $\mathrm{X}$-ray spectrum, high \% wt of $\mathrm{Si}$ and $\mathrm{O}$, with a proportion of $\sim 50 \% \mathrm{wt}$ between these two elements (1Si:2O). This group is separated into two subgroups: particles with relatively clean X-ray spectra ( $\mathrm{Si}$ and $\mathrm{O}$ with tubular and bright form) and particles with traces of other elements (irregular and bright agglomerates) (Table 2). Si-rich particles with traces of other elements could indicate that they come from longrange transport processes or remained in the atmosphere long enough to mix with those elements. In this type of particle, $\mathrm{Fe}$ has the highest \%wt (after Si and O). The origin of $\mathrm{Fe}$ is associated with soil dust. Si-rich particles may have a natural origin (resuspension of soil dust and earth's crust) and anthropogenic (coal burning and construction activities), although their source is primarily associated with soil (Xie et al. 2005; Cong et al. 2009; Boev et al. 2013; Geng et al. 2014; Pachauri et al. 2013; Margiotta et al. 2015;).

Construction activities were not found near the sampling station during sampling, so these particles' origin was considered natural. The morphology of these particles is sharpened with angular fragments, which indicates that it could be quartz of natural origin (Fig. 4c). Although atmospheric quartz dust can be in all particle size ranges (Eriksen Hammer et al. 2018), the Si-rich particles found in our study were in the coarse fraction.

1.4) Ti-containing group (relative abundance $4.49 \%$ )

Ti was present in minor amounts in most particles. Based on EDX's particle X-ray spectra, all particles containing Ti were separated to be studied further. Three subgroups were identified (Table 2).

Particles abundant in Ti element $(\mathrm{Ti}>10 \% \mathrm{wt})$ with Ti peaks in the X-ray spectrum are classified as Ti-rich. This particle's elemental composition shows high contents of $\mathrm{C}$ and $\mathrm{O}$ plus traces of soil-related elements. Ti oxide particles $\left(\mathrm{TiO}_{2}\right)$ have a natural and anthropogenic origin, e.g. resuspended unreacted mineral, dust, and metallurgical activities. In our study, according to its irregular morphology and size (coarse fraction), the Ti-rich particles come from crustal materials (Fig. 4d). During the sampling period, metallurgical activities occurred around the sampling station: this activity type cannot be discarded as Ti sources. However, the metal oxide particles emitted from the metallurgic industry usually present spherical shapes (Cong et al. 2009; Geng et al. 2014; Zeb et al. 2018; Eriksen Hammer et al. 2018).

Ti signals can also be observed in soil-derived aluminosilicate particles as they can have varying amounts of Ti in the mixture (Wawros et al. 2003; Gao et al. 2007; Campos et al. 2009; Boev et al. 2013; Pachauri et al. 2013; Geng et al. 2014; Mico et al. 2015; Margiotta et al. 2015; Eriksen Hammer et al. 2018; Zeb et al. 2018). The particles in this subgroup had $\mathrm{Mg}$ and $\mathrm{Fe}$ and other soilrelated elements that could indicate that they are a Femixture, probably montmorillonite or $\mathrm{Mg}$-vermiculite. The morphology of these particles was coarse, irregular, and bright, suggesting that they are soil-related aerosols.

The last subgroup is represented by $\mathrm{C}$-rich particles containing traces of Ti with sizes larger than $5 \mu \mathrm{m}$. They appeared irregular and bright. Carbon-rich particles are usually described either as carbonous mixtures or biological particles (Cong et al. 2009; Pachauri et al. 2013; Zeb et al. 2018). According to its morphology, one of these particles appears to be a carbonous mixture, and the others are biogenic aerosols mixed with Ti-containing aerosols like $\mathrm{TiO}_{2}$. C-rich particles are described in more detail later in this paper.

1.5) Ca-rich group (relative abundance 2.25\%)

Particles composed of high content of $\mathrm{Ca}(>10 \%$ relative contribution by weight) and high relative $\mathrm{X}$-ray intensities for $\mathrm{Ca}$ are classified as Ca-rich. In this group, there are two subgroups: calcite $\left(\mathrm{CaCO}_{3}\right)$ 
and dolomite $\left(\mathrm{MgCO}_{3} \cdot \mathrm{CaCO}_{3}\right)$, typical constituents of soils, often observed in aerosol/particle analysis. These particles were found in relatively low abundance (see Table 2). Sources for Ca-rich particles (calcite and/or dolomite) could be natural and anthropogenic like resuspended dust, crustal material from paved and unpaved roads or windblown dust, and construction activities (i.e. building, construction, demolition, and cement) (Hoornaert et al. 1996; Pachauri et al. 2013; Pipal et al. 2014; Mishra et al. 2015; Mico et al. 2015; Xie et al. 2005; Margiotta et al. 2015; Zeb et al. 2018). Airborne $\mathrm{CaCO}_{3}$ can be of marine origin as well (Hoornaert et al. 1996). Morphology of calcite and dolomite has been described as irregular fragments with distinct rough surfaces (Pachauri et al. 2013), pentagon-shaped (Zeb et al. 2018), irregular shape (Cong et al. 2009; Campos-Ramos et al. 2010; Mico et al. 2015), irregular and bright (Geng et al. 2014), and irregular bright aggregates (Mishra et al. 2015). Sizes of carbonate particles could range from 0.5 to $20 \mu \mathrm{m}$ (Wawros et al. 2003; Cong et al. 2009), meaning they are mainly in the coarse fraction (Mishra et al. 2015). According to the shape and fraction size, our Ca-rich particles are assumed to be soil-related calcium carbonates (Fig. 4e).

1.6) Cl-rich group (relative abundance $0.56 \%$ )

A big, well-defined, sharped, bright, Cl-rich crystal particle with a diameter bigger than $10 \mu \mathrm{m}$ was found in this study (Table 2 and Fig. 4f). It is characterised by the high relative $\mathrm{X}$-ray intensity of $\mathrm{Cl}$. It has $\mathrm{O}$ and $\mathrm{C}$ as major elements. Traces of $\mathrm{Si}$ and $\mathrm{Al}$ are present and could be because the hygroscopic behaviour of $\mathrm{NaCl}$ can encourage aggregation with silicate particles (Margiotta et al. 2015).

$\mathrm{Cl}$ aerosols can originate from industrial smokes, biomass burning, or sea salts (Wang et al. 2017). Zeb et al. (2018) found Cl-rich aerosols with tablet-like morphology and sizes $>5 \mu \mathrm{m}$; they mention that natural particles tend to be big, like sea salts or sea spray aerosols (SSA). Campos-Ramos et al. (2010) described the group of Cl-Na particles as well-defined crystals, with sizes between 5 and $10 \mu \mathrm{m}$, which are related to SSA. Geng et al. (2014) identified fresh SSA by the presence of $\mathrm{Na}$ and $\mathrm{Cl}$ peaks and often with minor $\mathrm{C}, \mathrm{O}, \mathrm{Mg}$, and $\mathrm{Ca}$ signals. Pipal et al. (2014) observed Cl-Na-rich aerosols in coarse particles coming from sea spray. OchsenkühnPetropoulou et al. (2009) show sodium chloride crystals as high brightness cubes in the coarse fraction originated from sea spray. Weinbruch et al. (2010) studied particle's characterisation on moss surfaces and interpreted $\mathrm{Cl}$ aerosols as marine. For Sielicki et al. (2011), Cl-rich particles are aerosols of sea salt brought with the wind to where samples were collected. Salt particles showed the typical cubic habit of regular square prisms. For Mico et al. (2015), fresh sea salt is presented in the form of crystals. Gao et al. (2007) demonstrated that a sea salt $(\mathrm{NaCl})$ particle with a similar shape that the one found in this study was associated with SSA. Reviews have mentioned that SSA can travel long trajectories becoming long-range atmospheric particles, and they can be mixed or react with the components of the atmosphere where they pass by (Mico et al. 2015; Weinbruch et al. 2010; Pipal et al. 2014; Geng et al. 2014).

Another source for $\mathrm{Cl}$-rich particles is garbage burning, which contributes to high concentrations of $\mathrm{HCl}$, mainly caused by the burning of polyvinyl chloride (PVC) or paper or high contents of food wastes in the garbage (Jiang et al. 2007; Moffet et al. 2008; Li et al. 2012). Particles from garbage burning are usually in the fine fraction ( $D p$ hundred $\mathrm{nm}$ ), and they are rounded (Zeuthen et al. 2007). Open garbage burning is a common practice to dispose of solid waste in the poor communities near the sampling station; therefore, it cannot be discarded as a possible source of $\mathrm{Cl}$ particles.

Based on its physical-chemical and morphological information, Cl-rich aerosols in this study are classified mainly as sea spray aerosols mixed with dust. Sea salt could be related to long trajectories of transported aerosols within air masses from the Caribbean Sea. Furthermore, $\mathrm{Cl}$ with more than $1 \%$ wt was present in 22\% of all particles analysed (without considering biogenic particles, as $\mathrm{Cl}$ is a tracer present in plants).

1.7) Mg-rich group (relative abundance $0.56 \%$ )

Aerosols containing a high \%wt of $\mathrm{Mg}(>20 \% \mathrm{wt})$ and pikes of $\mathrm{Mg}$ in the $\mathrm{X}$-ray spectrum are described as $\mathrm{Mg}$ rich (Table 2). These particles were magnesium carbonate $\left(\mathrm{MgCO}_{3}: \mathrm{Mg}, \mathrm{C}, \mathrm{O}\right.$ as major elements). Other studies of characterisation of atmospheric aerosols have found Mg-rich particles but have not described them (Sielicki et al. 2011; Geng et al. 2014; Eriksen Hammer et al. 2018). For Cong et al. (2009), $\mathrm{MgCO}_{3}$ ranged up to $10 \mu \mathrm{m}$ (coarse particles) and were assumed to be soil-related. For Geng et al. (2014), $\mathrm{MgCO}_{3}$ appeared irregular and bright, with strong $\mathrm{C}$, $\mathrm{O}$, and $\mathrm{Mg}$ signals in its X-ray spectrum. For this study, $\mathrm{Mg}$-rich particles were in the coarse fraction and are related to soil dust resuspended by wind or vehicles. Their morphology was smooth edges and bright (Fig. 4g). The roundness of this spray could be due to erosion by wind transport.

2) C-rich particles' category (relative abundance $31.45 \%$ )

C-rich particles were classified using clustering rules proposed by Matthias-Maser and Jaenicke (1991, 1994) and Coz et al. (2010). This category was classified into two groups: carbonous and biogenic aerosols (see Table 2). The 

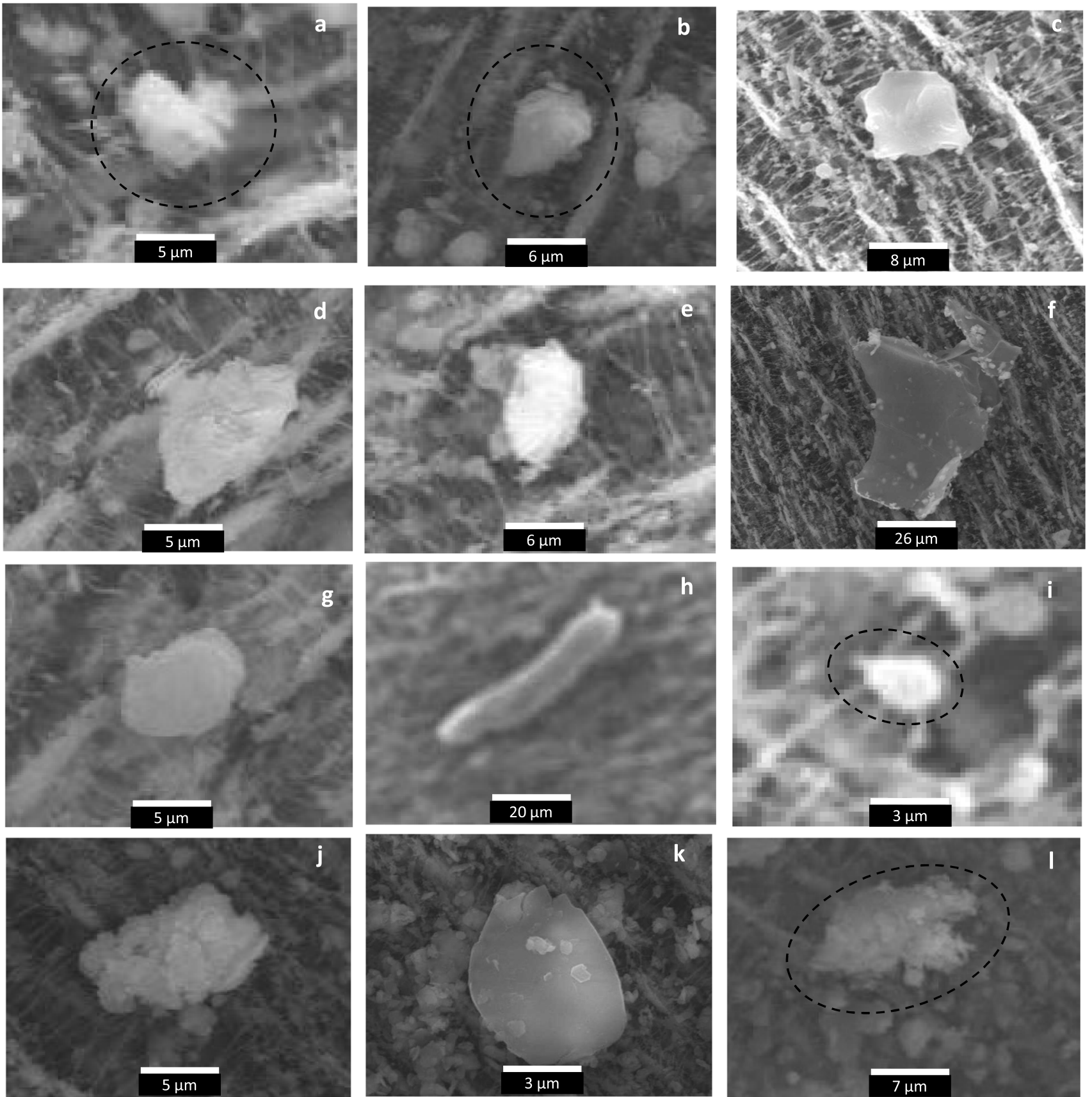

Fig. 4 SEM photomicrographs representing the different groups of particles analysed. Note: (a) Unreacted mineral dust (Fe-mixture without $\mathrm{Cl}$ ); (b) aluminosilicates (biotite); (c) Si-rich (quartz); (d) Ticontaining (Ti-rich); (e) Ca-rich; (f) Cl-rich; (g) Mg-rich; (h) C-rich:

subgroups are defined based on morphology and elemental composition.

2.1) Biogenic aerosols' group (relative abundance $16.29 \%)$

These other carbonaceous particles are dominated by biological aerosols classified based on their chemical biological; (i) C-rich: non-biological; (j) reacted (or mixed) ferrous aluminosilicates; (k) reacted (or aged) sea spray aerosols; (l) metals (Cu-containing). SEM photomicrographs representing the different groups of particles analysed

composition and/or characteristic morphology into four subgroups (see Table 1). This category has sizes larger than $10 \mu \mathrm{m}$ and highly variable morphologies (Cong et al. 2009; Pachauri et al. 2013; Zeb et al. 2018). The biological particles include microorganisms and organic fragments of all varieties of living matter, like viruses, bacteria, fungal spores, pollen, plant debris, animal mat- 
ter, protozoa, fungi, and/or fragments of leaves) (Xie et al. 2005; Cong et al. 2009; Pachauri et al. 2013; Boev et al. 2013; Zeb et al. 2018).

Among the subgroups are the biogenic aerosols' types 1,2 , and 3, containing minor amounts of $\mathrm{Na}, \mathrm{Mg}, \mathrm{K}, \mathrm{P}$, $\mathrm{Si}, \mathrm{Fe}, \mathrm{Cl}, \mathrm{Al}$, and $\mathrm{C}$, which are essential tracers present in plants. The subgroup of biogenic aerosols' type 1 is highly structured and has symmetrical shapes and sizes (mainly coarse particles from 2 to $25 \mu \mathrm{m}$ ) and is classified as a junk of plants. Biogenic aerosols' types 2 and 3 account for the other two subgroups. They have $\mathrm{C}$ and $\mathrm{O}$ as major amounts mixed with $\mathrm{Al}, \mathrm{Si}, \mathrm{Na}, \mathrm{Mg}, \mathrm{K}, \mathrm{Ca}$, and $\mathrm{Cl}$; these are particles of biological nature, differentiated by their morphology. The last subgroup is biologicalnatural, in which the origins are various forms of plants (leaf, flowers, branches) with $\mathrm{C}$ and $\mathrm{O}$ as only elements. Figure $4 \mathrm{~h}$ shows an example of a biological $\mathrm{C}$-rich particle found in this study.

2.2) Carbonous group (relative abundance $15.16 \%$ ).

2.2.1) High carbon aluminosilicates' subgroup (relative abundance $7.30 \%$ ).

These are particles with $\mathrm{C}-\mathrm{O}-\mathrm{Al}-\mathrm{Si}$ as major elements and a lower carbon and oxygen relation (\%wt). These aerosols also present traces of $\mathrm{Na}, \mathrm{Mg}, \mathrm{Cl}, \mathrm{K}, \mathrm{Ca}$, and Fe. Zeb et al. (2018), Pachauri et al. (2013), and Weinbruch et al. (2010) found similar particles, i.e. a mixture of carbonaceous and inorganic elements with varying amounts of soil-related components like $\mathrm{Si}, \mathrm{Na}, \mathrm{Mg}$, $\mathrm{K}, \mathrm{Cl}, \mathrm{Ca}$, and $\mathrm{Al}$ (as shown by their X-ray spectrum), forming complex aggregates with sizes from a few $\mathrm{nm}$ to several $\mu \mathrm{m}$ and variable morphologies.

2.2.2) Carbonaceous mixture with $\mathrm{S}$ subgroup (relative abundance $3.93 \%$ ).
A subgroup was created to recognise the possible presence of sulfur in the aerosols. This subgroup has a higher carbon than oxygen ratio (\%w) and the possible presence of sulfur and traces of other elements. Authors like Zeb et al. (2018) found a group of carbonaceous particles with $\mathrm{S}$ and traces of soil-related elements. Its morphology and elementary composition were similar to those of our study. Pachauri et al. (2013) indicate that these particles'sources are fuel, biomass, agricultural burning, and waste incineration. Carbonaceous particles' morphology is influenced by the type of power, burning conditions, and atmospheric processes. The $\mathrm{S}$ present in the particles is possible because $\mathrm{SO}_{2}$ can be adsorbed over mineral particle surfaces (Zeb et al. 2018) or by adsorption and secondary phases from $\mathrm{SO}_{4}$ present in the environment (Boev et al. 2013). $\mathrm{SO}_{2}$ comes from the burning of fossil fuel. The identification of $\mathrm{S}$ may be due to signal interference of $\mathrm{Au}$; this is further discussed later in the paper.

The above subgroups can be described as carbonous mixtures with dust-soot aggregates, including aluminosilicates, quartz, or Fe-mixtures that are externally mixed with carbon (Quinn et al. 2004; Gao et al. 2007; Cvetković et al. 2012).

2.2.3) High carbon and mineral subgroup (relative abundance $3.93 \%$ )

This subgroup has high carbon $(\mathrm{C}>50 \% \mathrm{wt})$, where the sum of $\mathrm{C}$ and $\mathrm{O}$ is $>90 \%$ wt plus traces of mineral elements. The aerosols of this group were differentiated according to the mineral elements' content: C-Cl, C-Cr, C-K, C-AlCl, $\mathrm{C}-\mathrm{NaClCaK}$, each of which had a particular morphology. These particles are interpreted as inorganic carbon coming from various sources (Fig. 4i).
Table 3 Factors of the main components of the composition of particulate material rotated by the Varimax method

\begin{tabular}{llrrrrr}
\hline Element & PC1 & \multicolumn{1}{c}{ PC2 } & \multicolumn{1}{c}{ PC3 } & \multicolumn{1}{c}{ PC4 } & PC5 & PC6 \\
\hline $\mathrm{C}$ & $\mathbf{- 0 . 9 3}$ & 0.01 & 0.05 & 0.15 & -0.16 & 0.05 \\
$\mathrm{O}$ & $\mathbf{0 . 8 2}$ & -0.08 & -0.07 & -0.29 & 0.23 & -0.18 \\
$\mathrm{Na}$ & 0.08 & $\mathbf{0 . 9 1}$ & 0.03 & -0.01 & 0.04 & 0.04 \\
$\mathrm{Mg}$ & 0.17 & 0.10 & 0.00 & 0.12 & $\mathbf{0 . 9 1}$ & 0.15 \\
$\mathrm{Al}$ & $\mathbf{0 . 8 6}$ & 0.06 & -0.05 & 0.10 & -0.04 & 0.03 \\
$\mathrm{Si}$ & $\mathbf{0 . 7 6}$ & -0.10 & -0.10 & 0.22 & -0.11 & 0.04 \\
$\mathrm{Cl}$ & -0.13 & $\mathbf{0 . 8 1}$ & 0.16 & 0.22 & 0.07 & -0.10 \\
$\mathrm{~K}$ & 0.10 & 0.16 & 0.06 & $\mathbf{0 . 9 2}$ & 0.12 & 0.02 \\
$\mathrm{Ti}$ & 0.00 & -0.04 & -0.03 & 0.02 & 0.13 & $\mathbf{0 . 9 6}$ \\
$\mathrm{Ca}$ & -0.16 & 0.16 & $\mathbf{0 . 7 7}$ & 0.12 & 0.25 & -0.17 \\
$\mathrm{Fe}$ & $\mathbf{0 . 7 4}$ & 0.05 & 0.12 & 0.27 & 0.19 & 0.20 \\
$\mathrm{~S}$ & 0.03 & 0.04 & $\mathbf{0 . 8 7}$ & -0.02 & -0.18 & 0.10 \\
Variability (\%) & 29.20 & 13.07 & 11.77 & 9.67 & 9.07 & 8.88 \\
Accummulated (\%) & 29.20 & 42.27 & 54.04 & 63.71 & 72.78 & 81.66 \\
\hline
\end{tabular}

Bold indicates highest loading for each element 
3) Secondary aerosols' category (relative abundance $10.00 \%)$

Mineral dust particles suspended (calcite, quartz, montmorillonite, feldspar, $\mathrm{Mg}$-vermiculite, and other aluminosilicates) are transported by winds to urban, industrial, and vegetation affluent areas. In that process, aerosols could mix with pollutants like sulfur compounds and nitrates emitted from anthropogenic sources, such as vehicles, small industries, and garbage burning, among others. Aerosols that have been through these processes reflect a mixed state (agglomeration, inclusions, internal/external mixing, coatings, etc.) caused by collisions or aerosols' coagulation in the atmosphere (Vester et al. 2007; Li et al. 2016; Bondy et al. 2018). The mixing of $\mathrm{S}$ in aerosols is possible due to the gasto-particle conversion of $\mathrm{SO}_{2}$ (De Bock et al. 2000). The precursor of sulfate particles is generally $\mathrm{SO}_{2}$, emitted by fossil fuels' combustion ( $\mathrm{Li}$ and Shao 2009).

Detection of sulphur in particles can be made by identifying the elemental S signal in the EDX analysis. However, US-EPA (2002) indicates that a gold coating over filters for better conductivity generates signals that can interfere with the elemental signals of the particles analysed by EDX. The Au EDX signal (Au: 2.12 and 9.71) is quite near the S EDX signal (S: 2.31), so sometimes they are not resolved into two well-differentiated peaks.

In this study, the Au interference on the $\mathrm{S}$ signal was managed by analysing filters on a case by case basis. As shown in Online Resource 3, the blank filter spectrum shows the gold signal. Au-coated samples showed that gold was not always evenly distributed on the filter, resulting in EDX spectra with low-to-none Au signals. Individual analysis of samples S2 and S4 shows that the two peaks (Au and $\mathrm{S}$ ) are present. However, in S6, the $\mathrm{S}$ was identified with no apparent Au presence (Online Resource 4).

Vehicles emit sulfur dioxide $\left(\mathrm{SO}_{2}\right)$ through the exhaust pipes during the vehicles' internal combustion process. It should be considered that Venezuelan gasoline contains more than $500 \mathrm{ppm}$ of sulfur compounds. In this research, a category of particles classified as secondary aerosols when they contain sulfur is proposed. The secondary aerosols were divided into two groups: reacted (or mixed) ferrous aluminosilicates (called reacted mineral dust) and reacted (or aged) sea spray aerosols (called sea spray aerosols reacted with mineral dust) (see Table 1). The former are Fe-containing minerals and $\mathrm{S}$, and the latter are $\mathrm{Na}$ - and/or Cl-containing mineral mixtures with $\mathrm{S}$.

The reacted mineral dust was divided into two subgroups according to morphology and the majority presence of Fe or Ca. For Geng et al. (2014), the reacted (or aged) mineral dusts were aluminosilicates, $\mathrm{CaCO}_{3}$, and
$\mathrm{CaMg}\left(\mathrm{CO}_{3}\right)_{2}$ mixed with $\mathrm{SO}_{2}$ and NOx or with "secondary acids" such as $\mathrm{H}_{2} \mathrm{SO}_{4}$ and $\mathrm{HNO}_{3}$. Its appearance was irregular and bright on their scanning electron images, sometimes enclosed or mixed with dark droplets, having $\mathrm{N}$ and/or S peaks in X-ray spectra, indicating that either nitrates, sulfates, or both were generated on their surface. For Gao et al. (2007), dust particles from Asia were often mixed with anthropogenic substances, internally by chemical reactions and externally by aggregation. They encountered clay containing $\mathrm{Fe}$ aerosols mixed with S. These particles present a morphology similar to those found in this research. Wawros et al. (2003), Xie et al. (2005), Mico et al. (2015), and Li et al. (2016) also reported soil aluminosilicates or mineral dust with minor amounts of S and irregular morphologies. Eriksen Hammer et al. (2018) reported complex secondary particles with mineral composition and $\mathrm{S}$ with no specific X-ray spectra or S peak. In this investigation, the reacted mineral dust particles are classified as mixtures of $\mathrm{Fe}$ or $\mathrm{Ca}$ dust resuspended with sulfur (Fig. 4j).

The reacted or aged SSAs were classified into three subgroups based on their SEMs and X-ray spectral data: (1) ClNaS-containing, (2) NaClS-containing, and (3) Na-rich-S (Table 1 and Fig. 4k). This subgrouping was done to emphasise how variable the chemistry and morphology of the $\mathrm{Na}-\mathrm{Cl}$ aerosols could be. These differences can be helpful for future identification of aerosols in upcoming research in the study area. Analysed aged sea salt has sodium and chlorine, but $\mathrm{Cl}$ is present in smaller quantities than in pure salts $(\mathrm{Cl}$ is quickly depleted into the atmosphere). Its morphology is usually smooth from long transport wind erosion. The reacted SSAs appear to have reacted with the $\mathrm{SO}_{2}$ in the air, resulting in $\mathrm{Na}-\mathrm{Cl}$ mixtures with $\mathrm{S}$. These particles generally have an irregular morphology. They have been reported in the coarse fraction. The classifications reflect similar NaClS aerosols in the bibliography (Gao et al. 2007; Vester et al. 2007; Geng et al. 2014; Mico et al. 2015; Li et al. 2016).

Our reacted or aged SSAs are mixed with mineral components. This mixup happens when dust particles enter a marine region during long-range transport. In this case, they are likely to mix with fresh or reacted SSAs, rapidly becoming a mixture of mineral, SSA, and/ or sulfate. Although our reacted SSAs have irregular morphology, there were particles with smooth rounded morphology resulting from wind erosion. Geng et al. (2014) and Eriksen Hammer et al. (2018) found reacted SSA particles mixed with mineral dust. These particles form part of the coarse fraction.

It is noteworthy to mention that the secondary dust category's information must be interpreted with caution 
due to the Au coating's quantitative interference in the $S$ signal in the EDX analysis.

4) Metallic particles' category (relative abundance $2.80 \%$ )

This category includes one group that contains $\mathrm{Fe}, \mathrm{Cu}$, $\mathrm{Nb}$, and $\mathrm{Co}$, combined with soil-related elements $\mathrm{Al}, \mathrm{Si}$, and $\mathrm{Ca}$. In this group, four subgroups were identified: iron oxide on silicate mineral, cobalt oxide, undefined ( $\mathrm{Cu}$-containing), and $\mathrm{Nb}$-aluminosilicate (Table 2).

Iron oxides on silicate minerals are referred to as Fe-rich particles $(\mathrm{Fe}>20 \%$ wt with strong $\mathrm{Fe}$ and $\mathrm{O}$ peaks in their $\mathrm{X}$-ray spectra). This type of aerosol is emitted from natural sources and human activities. However, Fe is mainly emitted from soil (Sah et al. 2019). Given that iron oxides from anthropogenic origin have spheroidal morphologies (Xie et al. 2005; Weinbruch et al. 2010; Campos-Ramos et al. 2010; Geng et al. 2014), the Fe-rich particles found in this investigation are classified as soil-related. Other studies found Fe-rich aerosols with similar morphology (CamposRamos et al. 2010; Weinbruch et al. 2010; Sielicki et al. 2011; Pachauri et al. 2013; Boev et al. 2013; Geng et al. 2014; Mico et al. 2015).

Road dust resuspended by vehicular activity could be enriched in $\mathrm{Ni}, \mathrm{Cr}$, andFe due to activities like wear and tear of tires, oil burning, abrasion of mechanical parts of vehicles, and oil lubricants (Pandey et al. 2012; Pachauri et al. 2013; Geng et al. 2014; Das et al. 2015; Elhadi et al. 2017; Sah et al. 2019). Cu is associated with the wearing of brakes, the automobile's oil pump, and corrosion of metal parts coming in contact with oil (Sah et al. 2019). $\mathrm{Fe}, \mathrm{Cu}$, $\mathrm{Co}$, and Ni could be originated from vehicle exhaust and brake wear (Wang et al. 2013). Based on their morphology and elemental composition, the common source attributed to the metallic particles in this study is road dust resuspension due to vehicular activity (Fig. 41).

On the other hand, $\mathrm{Nb}$ is related to metallurgic activities. This type of activity took place around the station during the sampling period. Since anthropogenic metal elements have been reported to be embedded into resuspended dust particles (Pachauri et al. 2013), the Nb-containing aerosols are classified as unreacted mineral dust mixed with $\mathrm{Nb}$ (Nb-aluminosilicate).

\section{Saharan dust influence}

Samples of June-July (S1-S7), analysed with FTIR, showed the greater signal intensity of mineral components than the samples of September-October (S8-S13) (see Figs. 1 and 2 ). This finding was verified statistically through the Student $t$ test applied for independent samples, using the $\mathrm{Si}-\mathrm{O}$ bond signal's average intensity at $1030 \mathrm{~cm}^{-1}$ for June-July and September-October. The Student $t$ test indicated that the average intensity was significantly higher in June-July than in September-October regardless of the sampling time: $48 \mathrm{~h}$ $(p=0.0051)$ or $100 \mathrm{~h}(p=0.0001)$. This result indicates a different source of mineral particles in June-July than in September-October.

Pearson's correlation was applied to assess whether precipitation, wind speed, and vehicular traffic influenced the variability of the concentration of mineral compounds represented by the $\mathrm{Si}-\mathrm{O}$ bond signal (see Fig. A6 in Online Resource 1). Wind speed was positively associated with the $\mathrm{Si}-\mathrm{O}$ bond signal $(r=0.727 ; p=0.010)$. $\mathrm{Si}-\mathrm{O}$ signal was associated with quartz and other aluminosilicates, whose origin is soil dust. At higher wind speeds, soil dust's resuspension is greater, generating a higher concentration of mineral compounds in the air (Athanasopoulou et al. 2010).

To further investigate the differences between samples collected in June-July and September-October, average elemental mass ratios were calculated for $\mathrm{Si} / \mathrm{Al}, \mathrm{K} / \mathrm{Al}, \mathrm{Fe} / \mathrm{Al}$, and $\mathrm{Fe} / \mathrm{Ca}$. The Mann-Whitney $U$ test was applied to establish statistical differences between samples collected in each period (Table in Online Resource 2). Results demonstrated the existence of significant differences with a $95 \%$ confidence interval, meaning the mineral dust could have various sources. $\mathrm{Si} / \mathrm{Al}$ and $\mathrm{Si} / \mathrm{Ca}$ ratios were higher in June-July than in September-October: samples in June-July had a more significant source of Si aerosols. The same could have happened for the Fe/ $\mathrm{Ca}$ ratio but Fe particles. Fe/Al ratio was lower in June-July, probably responding to $\mathrm{Al}$ aerosols' sources in these months.

According to the National Oceanic and Atmospheric Administration (NOAA), a Saharan dust episode was registered for June 27th-28th, 2018, which started as early as June 24th and reportedly lasted for 10 days, reaching South America (NOAA 2018-see Fig. A7 in Online Resource 1). Considering that Saharan air masses take 5 to 6 days to cross the Atlantic (Carlson and Prospero 1972), the possible contribution of African dust to the samples collected should not be ruled out. Furthermore, airborne dust from Africa that reaches the western Atlantic Ocean comprises various aluminosilicates, having high concentrations of $\mathrm{Si}$, Al, and Fe (Reid et al. 2003; Muhs et al. 2007; Prospero et al. 2014; Trapp et al. 2010). Therefore, the differences in the average elemental mass ratios shown in the Table in Online Resource 2 could reflect the influence of $\mathrm{Si}, \mathrm{Al}$, and $\mathrm{Fe}$ from this source. Note that, for a 26-year period study of PM in Caribbean sires, June and July are particularly marked by more frequent and more intense dusty events, May and August show an intermediate effect by desert dust particles, and September to April are mainly marked by marine particles-background atmosphere (EuphrasieClotilde et al. 2021). Moreover, the episode registered during the sampling period of this study was the only one; therefore, there is no evidence of any other Saharan dust episodes that could have affected the synoptic conditions of the September sampling period (S8-S13). 
Although there are no specific studies for characterising African dust in northern South America, several authors have suggested that dust reaching north South America should have similar characterisation across the region (Muhs et al. 2007; Prospero et al. 2014). Table in Online Resource 2 summarises the average elemental mass ratio for studies characterised by Saharan dust in different latitudes during the Boreal summer. $\mathrm{Si} / \mathrm{Al}$ and $\mathrm{Fe} / \mathrm{Al}$ ratios for June-July in this investigation show that the summer samples are similar to other studies reported during African dust episodes. Differences were found for $\mathrm{Fe} / \mathrm{Ca}$ and $\mathrm{Si} / \mathrm{Ca}$ ratios: most probably, these differences are related to the local source mix. Overall, results were similar to Chiapello (1996) for ratios in African dust transported over the Tropical North Atlantic.

In light of these considerations, ratios between minerals indicate that the Saharan episode of July 2018 significantly influenced PM sampling. According to the authors' knowledge, this study represents the first report to indicate that an episode of African dust could influence the particles collected in an intertropical continental sector in South America (Venezuela).

Fig. A8 a-b in Online Resource 1 indicates that the trends of silicate signals for 48 and $100 \mathrm{~h}$ are similar to each other (bands 797, 913, 938, and $1620 \mathrm{~cm}^{-1}$ ). Besides, signals of June-July have greater intensity than those of September-October (see $x$-axis). The signal for the carbonate functional group showed no specific tendency. Similarly, the carbonyl and aliphatic groups (i.e. ketones and carboxylic acids) for times of 48 and $100 \mathrm{~h}$ are similar (Fig. A8 c-d). The carboxylic groups in organic aerosols could be generated by photo-oxidation of anthropogenic and biogenic compounds (Satsumabayashi et al. 1989).

\section{Quantitative source appointment}

PCA was performed with PM's elemental composition (\%wt) obtained by SEM-EDX analysis. Six factors explain $81.66 \%$ of the variability (Table 3 ). The elements $\mathrm{Cu}, \mathrm{Nb}$, and $\mathrm{Cr}$ were discarded because they were only present in one or two particles. The first factor (PC1) explains $29.20 \%$ of the total variance. It showed a high positive correlation for $\mathrm{Si}, \mathrm{Al}, \mathrm{O}$, and $\mathrm{Fe}$, which correlated negatively with $\mathrm{C}$ (as the proportion of $\mathrm{C}$ increases, $\mathrm{Si}, \mathrm{Al}, \mathrm{O}$, and Fe decrease). The elements $\mathrm{Si}, \mathrm{Al}$, and $\mathrm{O}$ are characteristic of aluminosilicates and other unreacted mineral dust. When combined with $\mathrm{Fe}$, they are classified as clay, such as almandine or kaolinite (Kothai et al. 2011; Satsangi and Yadav 2014). PC1, therefore, represents a mixture of resuspended soil dust with a mostly non-mineral carbon source.

The second factor (PC2) explained variability of $13.07 \%$, showing a high positive correlation for $\mathrm{Na}-\mathrm{Cl}$, meaning they come from the same source (Kothai et al.
2011; Genga et al. 2012). These elements are mostly linked to marine aerosols or the combination of these within the soil dust due to sea salt deposition (Almeida et al. 2006; Kothai et al. 2011; Genga et al. 2012; Tomasi and Lupi 2017). Fine marine aerosols $(0.1-1 \mu \mathrm{m})$ can have a long life in the atmosphere and travel great distances (Fuzzi et al. 2015). Makowski Giannoni et al. (2016) found through statistical analysis of trajectories and a hybrid receiver model a strong impact of marine aerosols from the northern equatorial Atlantic, the Caribbean Sea, and the Pacific in southern Ecuador. May et al. (2018) found that particulate matter in a rural area in northern Michigan, more than $700 \mathrm{~km}$ from a nearby seawater body, contributed between 20 and $33 \%$ of marine aerosols, making it possible to find them in inland regions far from the coast. $\mathrm{Na}$ and Cl's traces were observed in unreacted mineral dust particles with irregular morphology in this study.

The third factor (PC3) explains $11.77 \%$ of the variability. It presents an association between $\mathrm{Ca}$ and $\mathrm{S}$ elements, indicating the possible presence of calcium sulfate. This factor could represent complex mixtures of calcium sulfate particles with mineral elements (Bondy et al. 2018).

Factors PC4, PC5, and PC6 together represent 27.62\% of the variability $(\mathrm{K}, \mathrm{Mg}$, and $\mathrm{Ti}$, respectively, without association). These elements are found as traces in the particles without a defined relationship. The potassium is commonly associated with the mineral origin and combustion of biomass (Ilacqua et al. 2007; Zeb et al. 2018). However, during the sampling period, there were no forest fires. Another source of potassium particles is soil dust, which can be found in the soil's mineral matter in the form of biotite or feldspar. No correlation was found with the remaining elements, so the presence of such minerals must be meagre. Magnesium sources are soil dust, marine aerosols, biomass burning, fossil fuels, and industrial processes (Jacobson 2002). Since Mg was not correlated with another element(s), the primary source is undefined. The titanium source is soil dust; since it is in small quantities, it is impossible to determine a preferential mineral source: Ti may be present in different clays (such as aluminosilicates rich in $\mathrm{Fe}$ and $\mathrm{Ti}$ ) or montmorillonite.

Fig. A9 in Online Resource 1 represents the dendrogram of the hierarchical cluster analysis (HCA). It shows that $\mathrm{C}$ is not associated with mineral elements, so it can be inferred that $\mathrm{C}$ is not of mineral origin. $\mathrm{Si}, \mathrm{O}, \mathrm{Al}$, and $\mathrm{Fe}$ are associated with each other and form the aluminosilicates group. Titanium forms a separate class, although it has a weak relationship with aluminosilicates, so it is reasonable to think it is present as soil dust traces. The elements $\mathrm{Na}$ and $\mathrm{Cl}$ are associated with each other; their source is attributed to sea salt. There is a relationship between $\mathrm{Mg}$ and $\mathrm{K}$. These elements have fewer similarities in the classification. $\mathrm{Mg}$ and $\mathrm{K}$ appear to be related to the $\mathrm{Na}-\mathrm{Cl}$ class and turn to the $\mathrm{Ca}-\mathrm{S}$ class. The association of $\mathrm{Ca}, \mathrm{S}, \mathrm{Na}, \mathrm{Cl}, \mathrm{Mg}$, and $\mathrm{K}$ has been referred 
to as particles of biological origin and as tracers present in plants (Cong et al. 2009; Coz et al. 2010; Zeb et al. 2018).

\section{Conclusions}

The SEM-EDX analysis found evidence of mineral elements related to soil and crustal origins (aluminosilicates and mineral dust), some of which were also identified by FTIR analysis due to characteristic absorption peaks spectra. By both analyses, the presence of C-rich or C-containing particles was found. By SEM-EDX analysis, some particles with varying amounts of $\mathrm{C}$ were associated with biological sources. By FTIR analysis, $\mathrm{C}$ was identified by several $\mathrm{C}$-containing functional groups associated with mineral and organic carbon. The presence of sulphur particles and sulphur-containing particles could not be fully confirmed in the infrared analysis because the Teflon filter FTIR spectra overlaps with the sulphur signal and, in the SEM analysis because the Au EDX signal interferes in the EDX spectra of sulphur: the Au EDX signal (Au: 2.12 and 9.71) is quite near the S EDX signal ( $\mathrm{S}: 2.31)$.

Morphological analysis of PM revealed that the following groups of particles were present: geogenic, metallic, and C-rich. In geogenic particles, unreacted mineral dust was the main contributor. C-rich particles were carbonaceous and biogenic aerosols. Morphological analysis showed that irregular particles in the coarse mode were dominant, indicating a higher presence of natural particles (rather than fine and spherical particles from combustion processes). For the sampling period, PM's sources in the Sartenejas Valley were mainly emissions from soil dust.

Quantitative source appointments through PCA showed PM sources were soil dust, sea salts, and reacted aerosols. The influence of carbon particles from non-mineral sources was also identified. The possible contribution of Sahara Desert dust was verified in samples from June to July. Considering that an episode of a Sahara dust storm was recorded in July 2018, the influence of this dust on our samples is not ruled out.

This study appears to be the first PM characterisation using SEM-EDX and ATR-FTIR in Greater Caracas, Venezuela. It also appears to be the first to report the influence of Saharan dust storms on PM's composition of the studied area.

\section{Data availability statement}

The datasets generated during and/or analysed during the current study are available from the corresponding author on reasonable request.

Supplementary Information The online version contains supplementary material available at https://doi.org/10.1007/s11869-021-01070-2.
Acknowledgements In this study, the Chemical Engineering students Ahilymar González and Yudeisy Buitrago from Universidad Simon Bolivar were crucial in the sampling period. To the Laboratorio de Carbón y Residuales de Petróleo for the support given. To the University of Nottingham for the support given covering the Article Processing Charges (APCs).

Open Access This article is licensed under a Creative Commons Attribution 4.0 International License, which permits use, sharing, adaptation, distribution and reproduction in any medium or format, as long as you give appropriate credit to the original author(s) and the source, provide a link to the Creative Commons licence, and indicate if changes were made. The images or other third party material in this article are included in the article's Creative Commons licence, unless indicated otherwise in a credit line to the material. If material is not included in the article's Creative Commons licence and your intended use is not permitted by statutory regulation or exceeds the permitted use, you will need to obtain permission directly from the copyright holder. To view a copy of this licence, visit http://creativecommons.org/licenses/by/4.0/.

\section{References}

Adams AM, Prospero JM, Zhang C (2012) CALIPSO-derived threedimensional structure of aerosol over the Atlantic Basin and adjacent continents. J Climate 25(19):6862-6879

Akhter MS, Chughtai A, Smith DM (1984) Reaction of hexane soot with nitrogen dioxide/nitrogen oxide $\left(\mathrm{N}_{2} \mathrm{O}_{4}\right)$. J Phys Chem-US 88(22):5334-5342

Allen DT, Palen EJ, Haimov MI, Hering SV, Young JR (1994) Fourier Transform Infrared Spectroscopy of Aerosol Collected in a Low Pressure Impactor (LPI/FTIR): Method Development and Field Calibration. Aerosol Sci Tech 21:325-342

Almeida SM, Pio CA, Freitas MC, Reis MA, Trancoso MA (2006) Approaching $\mathrm{PM}_{2.5}$ and $\mathrm{PM}_{2.5-10}$ source apportionment by mass balance analysis, principal component analysis and particle size distribution. Sci.Total Environ. 368(2-3), 663-674.

Anıl I, Golcuk K, Karaca F (2014) ATR-FTIR spectroscopic study of functional groups in aerosols: the contribution of a Saharan dust transport to urban atmosphere in Istanbul. Turkey Water Air Soil Poll 225(3): 1898

Apte JS, Marshall JD, Cohen AJ, Brauer M (2015) Addressing global mortality from ambient $\mathrm{PM}_{2.5}$. Environmental science \& technology, 49(13), pp. 8057-8066

Aragón-Piña, A. (2011). ¿Cómo son las partículas atmosféricas antropogénicas y cuál es su relación con los diversos tipos de fuentes contaminantes?, Groppe Libros, San Luis Potosí.

Aragón-Piña A (2011) ¿Cómo son las partículas atmosféricas antropogénicas y cuál es su relación con los diversos tipos de fuentes contaminantes?, Groppe Libros, San Luis Potosí

Athanasopoulou E, Tombrou M, Russell AG, Karanasiou A, Eleftheriadis K, Dandou A (2010) Implementation of road and soil dust emission parameterizations in the aerosol model CAMx: Applications over the greater Athens urban area affected by natural sources. J. Geophys Res-Atmos, 115(D17)

Atkinson RW, Kang S, Anderson HR, Mills IC, Walton HA (2014) Epidemiological time series studies of PM2. 5 and daily mortality and hospital admissions: a systematic review and metaanalysis. Thorax, 69(7), pp. 660-665

Bharti SK, Kumar D, Anand S, Barman SC, Kumar N (2017) Characterization and morphological analysis of individual aerosol of PM10 in urban area of Lucknow. India Micron 103:90-98 
Blando JD, Porcja RJ, Li TH, Bowman D, Lioy PJ, Turpin BJ (1998) Secondary formation and the Smoky Mountain organic aerosol: An examination of aerosol polarity and functional group composition during SEAVS. Environ Sci Technol 32(5):604-613

Błaszczak B (2018) The Use of Principal Component Analysis for Source Identification of PM2. 5 from Selected Urban and Regional Background Sites in Poland. E3S Web of Conferences, EDP Sciences

Boev I, Šijakova-Ivanova T, Mirakovski D (2013) Scanning electron microprobe characterization of air filters from the Kavadarci town and Tikveš valley. Geologica Macedonica 27(1):13-24

Bondy AL, Bonanno D, Moffet RC, Wang B, Laskin A, Ault AP (2018) The diverse chemical mixing state of aerosol particles in the southeastern United States. Atmos Chem Phys 18(16): 12595-12612

Campos A, Moreno S, Molina R (2009) Characterization of vermiculite by XRD and spectroscopic techniques. Earth Sci Res J 13(2):108-118

Campos-Ramos A, Piña AA, Querol X, Alastuey A (2010) Methodology for the characterization and identification by sem-eds of atmospheric particles from different pollutions emission. Microscopy: Science. Technology, Applications and Education 1:329-333

Carlson TN, Prospero JM (1972) The large-scale movement of Saharan air outbreaks over the northern equatorial Atlantic. J Appl Meteoro 11(2):283-297

Chavent M, Guegan H, Kuentz V, Patouille B, Saracco J (2009) PCAand PMF-based methodology for air pollution sources identification and apportionment. Environmetrics 20(8):928-942

Chiapello I (1996) Les aérosols atmosphériques au-dessus de l'Atlantique Nord Tropical: approche physicochimique et météorologique: évaluation de la contribution des différentes espèces à l'épaisseur optique en aérosol (Doctoral dissertation, Paris 7)

Claiborn C, Finn D, Larson T, Koenig J (2000) Windblown Dust Contributes to High PM25 Concentrations. J Air \& Waste Manage Assoc 50:1440-2144

Cohen AJ, Brauer M, Burnett R, Anderson HR, Frostad J, Estep K, ... Feigin V (2017) Estimates and 25-year trends of the global burden of disease attributable to ambient air pollution: an analysis of data from the Global Burden of Diseases Study 2015. The Lancet, 389(10082), pp. 1907-1918

Cong Z, Kang S, Dong S, Zhang Y (2009) Individual particle analysis of atmospheric aerosols at Nam Co. Tibetan Plateau Aerosol Air Qual Res 9(3):323-331

Coury C, Dillner AM (2009) ATR-FTIR characterization of organic functional groups and inorganic ions in ambient aerosols at a rural site. Atmos Environ 43(4):940-948

Coz E, Artíñano B, Clark LM, Hernandez M, Robinson AL, Casuccio GS, Lersh TL, Pandis SN (2010) Characterization of fine primary biogenic organic aerosol in an urban area in the northeastern United States. Atmos Environ 44(32):3952-3962

Cunningham PT, Johnson SA, Yang RT (1974) Variations in chemistry of airborne particulate material with particle size and time. Environ Sci Technol 8(2):131-135

Cvetković Ž, Logar M, Rosić A, Ćirić A (2012) Mineral composition of the airborne particles in the coal dust and fly ash of the Kolubara basin (Serbia). Period. Mineral. 81(2)

Das R, Khezri B, Srivastava B, Datta S, Sikdar PK, Webster RD, Wang X (2015) Trace element composition of PM2. 5 and PM10 from Kolkata-a heavily polluted Indian metropolis. Atmos Pollut Res 6(5): 742-750

De Bock LA, Joos PE, Noone KJ, Pockalny RA, Van Grieken RE (2000) Single particle analysis of aerosols, observed in the marine boundary layer during the Monterey Area Ship Tracks
Experiment (MAST), with respect to cloud droplet formation. J Atmos Chem 37(3):299-329

Duque Z, Castillo J, Mejías G, García S (2010) SEM-EDS in the Study of PM10. Acta Microscopica 19(3):312-321

Durdziński PT, Dunant CF, Haha MB, Scrivener KL (2015) A new quantification method based on SEM-EDS to assess fly ash composition and study the reaction of its individual components in hydrating cement paste. Cement Concrete Res 73:111-122

Elhadi RE, Abdullah AM, Abdullah AH, Ash'aari ZH, Dy G, Adamu A (2017) Source Identification of Heavy Metals in Particulate Matter (PM 10) in a Malaysian Traffic Area Using Multivariate Techniques. Pol. J. Environ. Stud. 26(6)

Engelstaedter S, Washington R, Mahowald N (2009) Impact of changes in atmospheric conditions in modulating summer dust concentration at Barbados: A back-trajectory analysis. J. Geophys ResAtmos, 114(D17)

Eriksen Hammer S, Mertes S, Schneider J, Ebert M, Kandler K, Weinbruch S (2018) Composition of ice particle residuals in mixed-phase clouds at Jungfraujoch (Switzerland): enrichment and depletion of particle groups relative to total aerosol. Atmos Chem Phys 18(19):13987-14003

Euphrasie-Clotilde L, Plocoste T, Brute FN (2021) Particle Size Analysis of African Dust Haze over the Last 20 Years: A Focus on the Extreme Event of June 2020. Atmosphere 12(4):502

Fišák J, Stoyanova V, Bartůňková K, Tesař M, Shoumkova A (2012) Typical Insoluble Particles in Fog Water at Milešovka Observatory (Czech Republic). Pure Appl Geophys 169(5-6): 1083-1091

Foghin-Pillin S (2012) Crónicas de pluviometría venezolana. Capítulo de libro : Perspectivas venezolanas sobre riesgos: reflexiones y experiencias Vol. II, pp. 295-322. Caracas: Sociedad Venezolana de Historia de las Geociencias/CENAMB-UCV, 2012

Foghin-Pillin S (2015) El año de las humaredas registro histórico de algunas sequías extremas en Venezuela. Culturales, (2)

Franklin M, Koutrakis P, Schwartz J (2008) The role of particle composition on the association between PM2. 5 and mortality. Epidemiology (Cambridge, Mass.), 19(5), pp. 680-689

Fuzzi S, Baltensperger U, Carslaw K, Decesari S, Denier van der Gon H, Facchini MC, Nemitz E (2015) Particulate matter, air quality and climate: lessons learned and future needs. Atmos Chem Phys 15(14):8217-8299

Gao Y, Anderson JR, Hua X (2007) Dust characteristics over the North Pacific observed through shipboard measurements during the ACE-Asia experiment. Atmos Environ 41(36):7907-7922

García N, Machado A, García C, Socorro E, Hernández H, Granda N (2002) Concentraciones atmosféricas de pts y su contenido de metales en una zona adyacente a una planta de cemento. Interciencia 27(9):476-481

Geng H, Hwang H, Liu X, Dong S, Ro CU (2014) Investigation of aged aerosols in size-resolved Asian dust storm particles transported from Beijing, China, to Incheon, Korea, using low-Z particle EPMA. Atmos Chem Phys 14(7):3307

Genga A, Baglivi F, Siciliano M, Siciliano T, Tepore M, Micocci G, Tortorella C, Aiello D (2012) SEM-EDS investigation on PM10 data collected in Central Italy: Principal Component Analysis and Hierarchical Cluster Analysis. Chem Cent J 6(2):1-15

Guajardo N, Ramírez A, Díaz F, Castillo E, Otero A, Parra J (2010) Concentración de las Partículas Totales Suspendidas en la atmósfera de Caracas. Revista De La Facultad De Ingeniería Universidad Central De Venezuela 25(2):73-80

HEI (2019) State of global air 2019. Tech. rept. Health Effects Institute Boston, MA

Hoornaert S, Van Malderen H, Van Grieken R (1996) Gypsum and other calcium-rich aerosol particles above the North Sea. Environ Sci Technol 30(5):1515-1520 
Huang X, Yin Y, Zhang B, Feng G (2018) Effects of the Structure and Composition of Montmorillonite on the Dimerization of Unsaturated Fatty Acids. J Brazil Chem Soc 29(7):1516-1526

Huda MN, Hossain SA, Islam MM, Islam MF (2018) Chemical and Morphological Characteristics of Particulate Matter Suspended in the Air of the Dhaka University Area of Bangladesh. Open Journal of Air Pollution 7(02):95

Ilacqua V, Hänninen O, Saarela K, Katsouyanni K, Künzli N, Jantunen M (2007) Source apportionment of population representative samples of PM2. 5 in three European cities using structural equation modelling. Sci. Total Environ. 384(1-3): 77-92

Jacobson MZ (2002) Atmospheric pollution: history, science, and regulation. Cambridge University Press

Ji Z, Dai R, Zhang Z (2015) Characterization of fine particulate matter in ambient air by combining TEM and multiple spectroscopic techniques-NMR, FTIR and Raman spectroscopy. Environ SciProc Imp 17(3):552-560

Jiang JG, Xin XU, Jun WANG, Yang SJ, Zhang Y (2007) Investigation of basic properties of fly ash from urban waste incinerators in China. J Environ Sci 19(4):458-463

Jung HJ, Kim B, Malek MA, Koo YS, Jung JH, Son YS, Kim JC, Kim H, Ro CU (2012) Chemical speciation of size-segregated floor dusts and airborne magnetic particles collected at underground subway stations in Seoul. Korea J Hazard Mater 213:331-340

Kandler K, Benker N, Bundke U, Cuevas E, Ebert M, Knippertz P, ..., Weinbruch S (2007) Chemical composition and complex refractive index of Saharan Mineral Dust at Izana, Tenerife (Spain) derived by electron microscopy. Atmos. Environ. 41(37): 8058-8074

Kothai P, Saradhi I, Pandit G, Markwitz A, Puranik V (2011) Chemical characterization and source identification of particulate matter at an urban site of Navi Mumbai. India Aerosol Air Qual Res 11(5):560-569

Li G, Lei W, Bei N, Molina LT (2012) Contribution of garbage burning to chloride and PM 2.5 in Mexico City. Atmos. Chem. Phys. 12(18): 8751-8761

Li W, Shao L, Zhang D, Ro CU, Hu M, Bi X, ..., Chen J (2016) A review of single aerosol particle studies in the atmosphere of East Asia: morphology, mixing state, source, and heterogeneous reactions. J. Clean Prod. 112: 1330-1349

Li WJ, Shao LY (2009) Observation of nitrate coatings on atmospheric mineral dust particles. Atmos Chem Phys 9(6):1863-1871

Loo B, Cork C (1988) Development of high efficiency virtual impactors. Aerosol Sci Technol 9(3):167-176

Machado A, Velázquez H, García N, García C, Acosta L, Córdova A, Linares M (2007) Metales en PM10 y su dispersión en una zona de alto tráfico vehicular. Interciencia 32(5):312-317

Machado A, García N, García C, Acosta L, Córdova A, Linares M, ..,. Velásquez H (2008) Contaminación por metales ( $\mathrm{Pb}, \mathrm{Zn}, \mathrm{Ni}$ y $\mathrm{Cr}$ ) en aire, sedimentos viales y suelo en una zona de alto tráfico vehicular. Revista internacional de contaminación ambiental, 24(4), 171-182

Makowski Giannoni S, Trachte K, Rollenbeck R, Lehnert L, Fuchs J, Bendix J (2016) Atmospheric salt deposition in a tropical mountain rainforest at the eastern Andean slopes of south Ecuador-Pacific or Atlantic origin? Atmos Chem Phys 16(15):10241-10261

Margiotta S, Lettino A, Speranza A, Summa V (2015) PM1 geochemical and mineralogical characterization using SEM-EDX to identify particle origin-Agri Valley pilot area (Basilicata, southern Italy). Nat Hazard Earth Sys 15(7):1551-1561

Maria SF, Russell LM, Turpin BJ, Porcja RJ (2002) FTIR measurements of functional groups and organic mass in aerosol samples over the Caribbean. Atmos Environ 36:5185-5196

Maria SF, Russell LM, Turpin BJ, Porcja RJ, Campos TL, Weber RJ, Huebert BJ (2003) Source signatures of carbon monoxide and organic functional groups in Asian Pacific Regional Aerosol Characterization Experiment (ACE-Asia) submicron aerosol types. J. Geophys. Res. 108(D23)

Martínez Y (1997) Partículas suspendidas totales y contenido de nitrato, cloruro y sulfato en el aire de dos zonas de valencia. Universidad de Carabobo, Venezuela, Facultad de Ingeniería, pp 163-174

Matthias-Maser S, Jaenicke R (1994) Examination of atmospheric bioaerosol particles with radii $>0.2 \mu \mathrm{m}$. J. Aerosol sci. 25(8): $1605-1613$

Matthias-MaserXI S, Jaenicke R (1991) A method to identify biological aerosol particles with radius $>0.3 \mu \mathrm{mfor}$ the determination of their size distribution. J Aerosol Sci 22:S849-S852

May NW, Gunsch MJ, Olson NE, Bondy AL, Kirpes RM, Bertman SB, ..., Pratt KA (2018) Unexpected contributions of sea spray and lake spray aerosol to inland particulate matter. Environ. Sci. Tech. Let. 5(7): 405-412

Mico S, Tsaousi E, Deda A, Pomonis P (2015) Characterization of airborne particles and source identification using SEM/EDS. European Chemical Bulletin 4(4-6):224-229

Mishra SK, Agnihotri R, Yadav PK, Singh S, Prasad MVSN, Praveen PS, ..., Sharma C (2015) Morphology of atmospheric particles over Semi-Arid region (Jaipur, Rajasthan) of India: Implications for optical properties. Aerosol Air Qual. Res. 15(3): 974-984

Moffet RC, Desyaterik Y, Hopkins RJ, Tivanski AV, Gilles MK, Wang $\mathrm{Y}$, ..., Mugica V (2008) Characterization of aerosols containing $\mathrm{Zn}, \mathrm{Pb}$, and $\mathrm{Cl}$ from an industrial region of Mexico City. Environ. Sci. Technol. 42(19): 7091-7097

Montes E, Hurinson C (2013) Evaluación espacio-temporal de la contaminación por partículas suspendidas totales en las parroquias del área metropolitana del municipio Maracaibo, Venezuela, 2001-20081. Perspectiva Geográfica: Revista Del Programa De Estudios De Posgrado En Geografía 18(2):217-238

Morales J, Cano Y, Sánchez L, Torres J, Stanislao I, Montilla B (2012) Evaluación preliminar de los niveles de partículas atmosféricas PM10 y PM2, 5 en la ciudad de Maracaibo. Venezuela Multiciencias 12(2):156-161

Morantes G, Pérez N, Santana R, Rincón G (2016) Revisión de instrumentos normativos de la calidad del aire y sistemas de monitoreo atmosférico: América Latina y el Caribe. Interciencia 41(4):235-242

Morantes GR, Rincón G, Pérez NA (2019) Modelo de regresión lineal multiple para estimar concentración de PM1. Revista Internacional De Contaminación Ambiental 35(1):179-194

Muhs DR, Budahn JR, Prospero JM, Carey SN (2007) Geochemical evidence for African dust inputs to soils of western Atlantic islands: Barbados, the Bahamas, and Florida. J Geophys ResEarth, 112(F2)

NOAA [@NOAASatellites] (2018) That's not a smudge on your screen, this morning \#GOESEast captured a Full Disk Earth view of the major Saharan \#dust blowing across the Atlantic [Tweet]. Twitter https://twitter.com/NOAASatellites/status/1011955269 910384645

Ochsenkühn-Petropoulou M, Lyberopoulou T, Argyropoulou R, Tsopelas F, Ochsenkühn KM (2009) Chemical and structural characterization of airborne particulate matter in an industrial and an urban area in Greece. Fresen Environ Bull 18(11):2210-2217

Pachauri T, Satsangi A, Singla V, Lakhani A, Kumari KM (2013) Characteristics and sources of carbonaceous aerosols in PM2. 5 during wintertime in Agra, India. Aerosol Air Qual. Res. 13(3): 977-991

Pandey P, Khan AH, Verma AK, Singh KA, Mathur N, Kisku GC, Barman SC (2012) Seasonal trends of PM 2.5 and PM 10 in ambient air and their correlation in ambient air of Lucknow City, India. B. Environ. Contam. Tox. 88(2): 265-270

Pipal AS, Jan R, Satsangi PG, Tiwari S, Taneja A (2014) Study of surface morphology, elemental composition and origin of 
atmospheric aerosols (PM2. 5 and PM10) over Agra, India. Aerosol Air Qual. Res. 14(6): 1685-1700

Prospero JM, Collard FX, Molinié J, Jeannot A (2014) Characterizing the annual cycle of African dust transport to the Caribbean Basin and South America and its impact on the environment and air quality. Global Biogeochem Cy 28(7):757-773

Quinn PK, Coffman DJ, Bates TS, Welton EJ, Covert DS, Miller TL, ..., Carrico CM (2004) Aerosol optical properties measured on board the Ronald $\mathrm{H}$. Brown during ACE-Asia as a function of aerosol chemical composition and source region. J. Geophys. Res-Atmos. 109(D19)

Radulescu C, Stihi C, Iordache S, Dunea D, Dulama I (2017) Characterization of urban atmospheric PM2. 5 by ATR-FTIR. ICP-MS and SEM-EDS Techniques Rev Chim 68:805-810

Ramírez L (2012) Evolución 1982-2007 de los Estratos Sociales en Venezuela y su Conexión con la Elección Presidencial 2012. Mundo Universitario, $\mathrm{N}^{\circ} 41$, Vol X (3), 311-322.

Ramos C, Vicentini A, Ortega D (2012) Challenges and opportunities of waste collection in Caracas: Sucre municipality case study. Consilience 7:115-129

Reff A, Turpin BJ, Porcja RJ, Giovennetti R, Cui W, Weisel CP, Zhang $\mathrm{J}$ et al (2005) Functional group characterization of indoor, outdoor, and personal PM2.5: results from RIOPA. Indoor Air 15:53-61

Reid EA, Reid JS, Meier MM, Dunlap MR, Cliff SS, Broumas A, ..., Maring H (2003) Characterization of African dust transported to Puerto Rico by individual particle and size segregated bulk analysis. J. Geophys Res-Atmos, 108(D19)

Rincón G, Cremades LV (2012) Assessment of responsibility for pollution from PM10 and sulfur dioxide and application to an industrial area on the northeastern coast of Venezuela. Aerosol and Air Quality Research 12(5):722-732

Sah D, Verma PK, Kandikonda MK, Lakhani A (2019) Pollution characteristics, human health risk through multiple exposure pathways, and source apportionment of heavy metals in PM10 at Indo-Gangetic site. Urban Climate 27:149-162

Saikia BJ, Parthasarathy G (2010) Fourier transform infrared spectroscopic characterization of kaolinite from Assam and Meghalaya, Northeastern India. J Mod Phys 1(04):206

Saikia BJ, Parthasarathy G, Borah RR, Borthakur R (2016) Raman and FTIR spectroscopic evaluation of clay minerals and estimation of metal contaminations in natural deposition of surface sediments from Brahmaputra river. Int J Geosci 7(07):873

Satsangi PG, Yadav S (2014) Characterization of PM2.5 by X-ray diffraction and scanning electron microscopy-energy dispersive spectrometer: its relation with different pollution sources. Int $\mathbf{J}$ Environ Sci Technol 11:217-232

Satsumabayashi H, Kurita H, Yokouchi Y, Ueda H (1989) Mono-and di-carboxylic acids under long-range transport of air pollution in central Japan. Tellus b: Chemical and Physical Meteorology 41(3):219-229

Seinfeld JH, Pandis SN (2016) Atmospheric chemistry and physics: from air pollution to climate change, 3rd edn. John Wiley \& Sons Inc, Hoboken, New Jersey

Senthil Kumar R, Rajkumar P (2013) Characterization of minerals in air dust particles in the state of Tamilnadu, India through ftir spectroscopy. Atmospheric Chemistry and Physics Discussions 13(8):22221-22248

Shaka' H, Saliba A (2004) Concentration measurements and chemical composition of PM10-2.5 and PM2. 5 at a coastal site in Beirut, Lebanon. Atmos. Environ. 38(4): 523-531

Sielicki P, Janik H, Guzman A, Reynolds A, Namieśnik J (2011) Analysis of airborne metal containing particles with EDX/EDS detectors in electron microscopes. Open Chem 9(2):308-313

Thermo Fisher Scientific Inc. (2011) Partisol 2000i Air Sampler/Partisol 2000i-D Dichotomous Air Sampler Instruction Manual
Tomasi C, Lupi A (2017) Primary and secondary sources of atmospheric aerosol. Atmospheric Aerosols; Wiley-VCH Verlag GmbH \& Co. KGaA: Weinheim, Germany

Trapp JM, Millero FJ, Prospero JM (2010) Temporal variability of the elemental composition of African dust measured in trade wind aerosols at Barbados and Miami. Mar Chem 120(1-4):71-82

Tsitouridou R, Papazova P, Simeonova P, Simeonov V (2013) Chemical and statistical interpretation of sized aerosol particles collected at an urban site in Thessaloniki. Greece J Environ Sci Heal a 48(14): $1815-1828$

US-EPA (2002) Guidelines for the Application of SEM/EDX Analytical Techniques to Particulate Matter Samples. EPA-600/R-02-070

Vester BP, Ebert M, Barnert EB, Schneider J, Kandler K, Schütz L, Weinbruch S (2007) Composition and mixing state of the urban background aerosol in the Rhein-Main area (Germany). Atmos Environ 41(29):6102-6115

Wagner J, Wang Z, Ghosal S, Wall S (2019) Source Identification on High PM2.5 Days Using SEM/EDS, XRF, Raman, and Windblown Dust Modeling. Aerosol Air Qual Res 19:2518-2530

Wagner, J. and Casuccio, G. (2014). Spectral imaging and passive sampling to investigate particle sources in urban desert regions. Environ. Sci.: Processes Impacts. 16: 1745-1753.

Wang J, Hu Z, Chen Y, Chen Z, Xu S (2013) Contamination characteristics and possible sources of PM10 and PM2. 5 in different functional areas of Shanghai. China Atmos Environ 68:221-229

Wang H, Wang X, Yang X, Li W, Xue L, Wang T, ..., Wang W (2017) Mixed Chloride Aerosols and their Atmospheric Implications: A Review. Aerosol Air Qual Res 17(4): 878-887

Wang Y, Shi Z, Shen F, Sun J, Huang L, Zhang H, ..., Hu J (2019) Associations of daily mortality with short-term exposure to PM2. 5 and its constituents in Shanghai, China. Chemosphere, 233, 879-887

Wawros, A., Talik, E., Zelechower, M., Pastuszka, J. S., Skrzypek, D., \& Ujma, Z. (2003). Seasonal Variation in the Chemical Composition and Morphology of Aerosol Particles in the Centre of Katowice, Poland. Pol. J. Environ. Stud. 12(5).

Weakley AT, Takahama S, Dillner AM (2016) Ambient Aerosol Composition by Infrared Spectroscopy and Partial Least-Squares in the Chemical Speciation Network: Organic Carbon with Functional Group Identification. Aerosol Sci Technol 50:1096-1114

Weinbruch S, Ebert M, Gorzawski H, Dirsch T, Berg T, Steinnes E (2010) Characterisation of individual aerosol particles on moss surfaces: implications for source apportionment. J Environ Monitor 12(5): 1064-1071

World Health Organization (2006) WHO Air quality guidelines for particulate matter, ozone, nitrogen dioxide and sulfur dioxide: global update 2005: summary of risk assessment (No. WHO/SDE/PHE/ OEH/06.02). Geneva: World Health Organization

Xie RK, Seip HM, Leinum JR, Winje T, Xiao JS (2005) Chemical characterization of individual particles (PM10) from ambient air in Guiyang City. China Sci Total Environ 343(1-3):261-272

Yin P, Guo J, Wang L, Fan W, Lu F, Guo M, ..., Dong Z (2020) Higher risk of cardiovascular disease associated with smaller size-fractioned particulate matter. Environ Sci Technol Lett, 7:(2)95-101

Yu X, Song W, Yu Q, Li S, Zhu M, Zhang Y, ..., Wang, X (2018) Fast screening compositions of PM2. 5 by ATR-FTIR: Comparison with results from IC andOC/EC analyzers. J Environ Sci 71:76-88

Zeb B, Alam K, Sorooshian A, Blaschke T, Ahmad I, Shahid I (2018) On the morphology and composition of particulate matter in an urban environment. Aerosol Air Qual Res 18(6):1431

Zeuthen JH, Pedersen AJ, Hansen J, Frandsen FJ, Livbjerg H, Riber C, Astrup T (2007) Combustion aerosols from municipal waste incineration-effect of fuel feedstock and plant operation. Combust Sci Technol 179(10):2171-2198

Publisher's note Springer Nature remains neutral with regard to jurisdictional claims in published maps and institutional affiliations. 